Article

\title{
Sustainable Agronomic Strategies for Enhancing the Yield and Nutritional Quality of Wild Tomato, Solanum Lycopersicum (1) Var Cerasiforme Mill
}

\author{
Kanagaraj Muthu-Pandian Chanthini, Vethamonickam Stanley-Raja, Annamalai Thanigaivel, \\ Sengodan Karthi, Radhakrishnan Palanikani, Narayanan Shyam Sundar, Haridoss Sivanesh, \\ Ramaiah Soranam and Sengottayan Senthil-Nathan *
}

Sri Paramakalyani Centre for Excellence in Environmental Sciences, Manonmaniam Sundaranar University, Alwarkurichi, Tirunelveli 627412, Tamil-Nadu, India; clairdelune127@gmail.com (K.M.-P.C.); stanleyraja@gmail.com (V.S.-R.); www.thani@gmail.com (A.T.); karthientomology@gmail.com (S.K.); kani.palani5@gmail.com (R.P.); krn.shyamsundar@gmail.com (N.S.S.); Sivanesh2020@gmail.com (H.S.); soranamr@gmail.com (R.S.)

* Correspondence: senthil@msuniv.ac.in; Tel.: +91-463-428-3066

Received: 30 April 2019; Accepted: 28 May 2019; Published: 13 June 2019

\begin{abstract}
Urbanization and global climate change have constrained plant development and yield. Utilization of wild gene pool, together with the application of sustainable and eco-friendly agronomic crop improvement strategies, is being focused on to tackle mounting food insecurity issues. In this aspect, the green seaweed, Ulva flexuosa, was assessed for plant biostimulant potential on cherry tomato, in terms of seed priming effects, nutrition and yield. SEM-EDX analysis of $U$. flexuosa presented the occurrence of cell wall elements $(\mathrm{O}, \mathrm{Na}, \mathrm{Mg}, \mathrm{S}, \mathrm{Cl}, \mathrm{K}$ and $\mathrm{Ca})$. The phytochemical analyses of liquid seaweed extract (EF-LSE) revealed the presence of carbohydrates, protein, phenols, flavonoids, saponins, tannins and coumarins. The EF-LSEs were found to stimulate seed germination in a dose-dependent manner, recording higher seed germination, and biomass and growth parameters. The seedlings of treated seeds altered the biochemical profile of the fruit, in terms of TSS (93\%), phenol $(92 \%)$, lycopene $(12 \%)$ and ascorbic acid $(86.8 \%)$. The EF-LSEs positively influenced fruit yield $(97 \%)$. Henceforth, this investigation brings to light the plant biostimulant potential of the under-utilized seaweed source, $U$. flexuosa, to be useful as a bio fertilizer in agronomic fields for a cumulative enhancement of crop vigour as well as yields to meet the growing food demands.
\end{abstract}

Keywords: seed priming; seaweed extract; biostimulant; germination energy; seedling vigour

\section{Introduction}

Agriculture is facing various crises that are worsening with time. Increasing food production to meet or feed the mounting population is a foremost challenge. This can be accomplished by further use of farm lands for an overall hike in food production or technically enhancing the yields from pre-existing lands by application of fertilizers or implementation of novel approaches; for instance, precision farming systems viz., cutting-edge irrigation arrangements, and ecologically accomplishable crop revolutions [1]. Crop diseases decrease yield, resulting in a prominent crisis to food security, creating a global malnutrition spree affecting nearly 815 million people [2]. Henceforward, natural fertilizers are well thought out as probable as well as safe alternatives to chemical fertilizers [3]. Additionally, the presence of several horticultural important traits in the wild gene pool makes them suitable as potential breeding candidates for crop improvement [4]. In this aspect, plant secondary metabolites are being emphasized for their disease regulator competences and combined in more than a few defense control programs [5]. 
The marine ecosystem serves as a rich source of bioactive compounds, such as sulfated polysaccharides, terpenoids, phenolics, lactones, sterol and fatty acids, possessing pharmacological and plant growth-stimulating properties [6]. Seaweeds form a key portion of these bioactive natural composites, with over 9000 species, known for their biostimulator potentials. Additionally, seaweed products as biostimulants that can enhance crop production are also being focused on. Biostimulants are materials supplementary to fertilizers, which endorse plant growth at lower concentrations [7]. In addition, seaweeds are extensively applied in the fields of agriculture and horticulture to improve quality and quantity, and the results are promising [8]. Innumerable seaweeds are being applied as liquid fertilizers to upsurge crop yields, as they are rich in macro-nutrients, besides trace elements essential for the development and enrichment of plants. Commercial seaweed products are also being marketed successfully [9]. Besides being inexpensive, the seaweed extracts have surplus allelopathic chemicals that promote seed germination as well as emergence rates. Seaweed extracts are known to have a positive impact on prime stages of plant ontogenesis-starting from seed germination to seedling growth [10]. Furthermore, seaweeds are reported with higher amounts of growth hormones, attributed to their plant biostimulant activities [11].

Seed germination is a decisive procedure in plant growth, and the enrichment of germination potentialities of a seed can eventually enable a surge in crop yields, and is dependent on numerous chemical factors (soil moisture salinity, metal, mineral composition) [12]. The emergence of seed is promoted by various methods for enhanced agricultural yields, like exposing them to biostimulants or growth promoting hormones by the process of seed priming. As the very first stage of plant growth, germination is defined as an outcrop of the radicle from the tissues enfolding the seed [13]. As germination rates may vary among species, the analyses of germination rates might be directly proportional to the growth rates and consequently, their yields [14,15].

Cherry tomato, Solanum lycopersicum (L.) var. cerasiforme Mill. is a widespread, table purpose tomato variety, bearing bright red color, and small fruits. It is a probable ancestor of a cultivated tomato variety with small fruits bright red in color, resembling a cherry and tasting excellent [16]. They are also favorable candidates in breeding programs for their genetic diversity, offering the selection of parental traits along with extensive geographic ranges. [17]. With the debarring effects of crop growth promoting chemicals that alter soil ecology and have hazardous environmental and health impacts, researchers are concentrating on the allegation of naturally benign substitutes to increase yields, while offering effective crop protection. The favorable agronomic traits of cherry tomato (an intermediary genetic admixture flanked by wild currant-type tomatoes and domesticated garden tomatoes), such as higher nutrient composition, offer plans for balanced utilization to unravel indigenous complications encompassing crop adaptation to climatic variations or, to endorse functional food consumption [18].

Seed priming of native seed species can evoke ecological restoration, stimulating the expression of dormant genes responsible for the expression of favorable agronomic traits. Since the sources of natural varieties are collected from the wild and their sources are limited, there is a persistent requirement for novel methods for seed-based restoration technologies. In this aspect, seed priming could be a strategy for sustainable seedling establishment, plant growth, and restoration of native seed. Hence, this research intended to discover the bio stimulator potentials of liquid seaweed extract of green alga, $U$. flexuosa, along with screening of their phytochemical and elemental composition on cherry tomato.

\section{Materials and Methods}

\subsection{Seed Collection and Preparation}

Cherry tomato seeds, variety ATL-01-19, were purchased from Tamil Nadu Agricultural University, Coimbatore, Tamil Nadu, India. Seeds of undeviating dimensions and hue were carefully chosen for the study, surface sterilized with $0.1 \%$ mercuric chloride, washed thrice in sterile distilled water. The experiment was carried out at Sri Paramakalyani Centre for Excellence in Environmental Science, Manonmaniam Sundaranar University, Alwarkurichi, from July to August, 2018. 


\subsection{Seaweed Collection}

The seaweed, Ulva flexuosa (Ulvaceae), was collected from the rocks in coastal areas at Colachel beach (Figure 1), Kanyakumari $\left(8^{\circ} 14^{\prime} 5168^{\prime \prime} \mathrm{N}\right.$ and $77^{\circ} 14^{\prime} 35.209^{\prime \prime}$ E) during a low tide period (August 2018). It was washed in seawater several times to remove impurities, sand particles, and epiphytes, and brought to the research laboratory in taped up polythene bags. The seaweed was washed thoroughly in tap water several times, wearied and spread on blotting paper to remove excess water, and shade dried for 2 to 3 hours.

\subsection{Preparation of Starter Fertilizer Solution (SFS)}

Ammonium dihydrogen phosphate (Merck) was used as a starter fertilizer solution by mixing $1 \mathrm{mg}$ of $\mathrm{NH}_{4} \mathrm{H}_{2} \mathrm{PO}_{4}$ in sterile distilled water $(10 \mathrm{~mL})$, designated as positive control.

\subsection{Preparations of Liquid Seaweed Extract (EF-LSE)}

The washed seaweed was then cut into minor fragments, boiled in distilled water (100 gms/1 L) for one hour in an autoclave $\left(121^{\circ} \mathrm{C}, 15 \mathrm{psi}\right.$ of pressure), and filtered through a cheese cloth (double layered), yielding $890 \mathrm{ml}$ of LSE. The LSE was stored at $4{ }^{\circ} \mathrm{C}$ in a refrigerator until further use. The test concentrations of EF-LSE were prepared by diluting the extract with distilled water $(20 \%, 40 \%, 60 \%$, $80 \%$ and $100 \%)$.

\subsection{EF-LSE Analysis}

\subsubsection{Physicochemical Analysis}

Physicochemical structures of the EF-LSEs- $\mathrm{pH}$, electrical conductivity, and color appearance-was determined. $\mathrm{pH}$ was determined using a $\mathrm{pH}$ meter (ELICO LI 120, Hyderabad, India), whereas conductivity was done with the help of a conductivity meter (Microprocessor EC Meter 1615, Parwanoo, Himachal Pradesh, India) and expressed in ds/m. The colour of the EF-LSE was visually observed and noted.

\subsubsection{Elemental Composition of EF-LSE Using X-ray-Energy Dispersive Spectroscopic (ED) Analysis}

The elemental composition of $U$. flexuosa was performed using EDAX (BRUKER) to elucidate the components present in the seaweed cell wall.

\subsubsection{Phytochemical and Biochemical Screening}

Phytochemical [19] and biochemical screening of $U$. flexuosa was performed to analyse the quantitative amounts of phenol [20], chlorophyll [21] and protein [22] by standard procedures.

\subsection{Preparation of Seeds}

Tomato seeds, tomato wild relative, Solanum lycopersicum (L.) var. cerasiforme Mill, were used for all the tests. Tomato seeds, without any visible signs of infection, of uniform size, shape and colour, were carefully chosen, surface sterilized using $0.1 \%$ mercuric chloride, before and after rinsing in sterile distilled water. The seeds were used for further analysis.

To investigate the possible effects of UF-LSEs on tomato plant's vegetative growth and yield, small pot field experiments containing sterilized soil were conducted by sowing the primed seeds in a tray. The seedlings (2-3 true leaf stage) were transplanted into autoclaved pot mixture (red soil: cow dung: vermiculate at $2: 1: 1, \mathrm{w} / \mathrm{w} / \mathrm{w})$ in the surface sterilized ( $1 \%$ mercuric chloride) pots $(15 \mathrm{~cm}$ diameter, $750 \mathrm{~mL}$ volume) at 1 seedling/pot. The pots were labeled based on the treatments. Vegetative growth parameters were analyzed by sampling from seedlings selected from randomized block designs. 


\subsection{Biostimulant Assays}

\subsubsection{Seed Bioassay}

\section{Seed Germination Test}

Seed germination assay was conducted using five surface sterilised seeds per assay, replicated five times. The seeds were exposed to EF-LSE extracts $(10 \mathrm{~mL}), \mathrm{SFS}$ in sealed and labelled conical flasks and kept in a shaker for 12 hours. Seeds in $10 \mathrm{~mL}$ sterile distilled water were used as control. The seeds were then removed and spread on a filter paper to blot out the solutions at room temperature for 24 hours. The treated seeds were placed in pre-labelled sterile petri dishes $(9 \mathrm{~cm})$ over filter paper (Whatman No. 5) that was moistened (sterile distilled water), instantaneously taped up with parafilm (Merck) to prevent moisture loss, and incubated $\left(25 \pm 2{ }^{\circ} \mathrm{C} /\right.$ alternative $16 \mathrm{~h}$ light- $8 \mathrm{~h}$ dark). The plates were checked for radicle protrusion $(>2 \mathrm{~mm}$ ) on a daily basis (hint of germination). Ten seeds were tested for each concentration of EF-LSE.

Germination was recorded every day by counting the emerging hypocotyls. The mean germination time (MGT) was premeditated [23] by counts made on the time taken for $1 \%, 10 \%, 25 \%, 50 \%, 75 \%$ and $100 \%$ of the seeds to germinate and expressed as days.

$$
\mathrm{MGT}=\frac{\Sigma(n \mathrm{~T})}{\sum n}
$$

where,

$n=$ number of newly germinated seeds at time $\mathrm{T}\left(25^{\circ} \mathrm{C}\right)$

$\mathrm{T}=$ hours from the beginning of the germination test

$\Sigma n=$ final germination

${ }^{*} 100 \%$ will refer to the total number of seeds germinated after exposure to the highest EF-LSE concentration.

The germination percentage (GP) was calculated using the following formula:

$$
\mathrm{GP}=\frac{\text { Number of seeds germinated }}{\text { Total number of seeds }} \times 100
$$

Seed Germination Energy (GE) was calculated according to the following formula:

$$
\mathrm{GE}=\frac{\text { Number of germinating seeds }}{\text { No. of total seeds per test post germination for } 3 \text { days }} \times 100
$$

Seedling vigour index (SVI) SVI was calculated [24] by the following formula:

$$
\text { SVI }=\text { Seedling length }(\mathrm{cm}) \times \text { germination } \%
$$

Seed Imbibition

The biomass (wet and dry weight, $\mathrm{mg}$ ) of the seeds primed in EF-LSEs and SFS solutions for 24 hours were determined with the help of an electronic balance after oven-drying at $40{ }^{\circ} \mathrm{C}$ for two days. Seed imbibition was determined by measuring the weight of seeds (100 seeds/treatment) before and during priming with SFS and EF-LSEs at 6, 12, 24, 36 and 48 hours and plotting the water imbibition curve by determining the seed moisture content (MC) and through means of which, the seed imbibition time was calculated [25]. Seeds primed in distilled water served as control. The MC was calculated by the formula:

$$
\text { Moisture content }=\frac{\text { Fresh weight }- \text { Dry weight }}{\text { Dry weight }} \times 100
$$




\subsubsection{Growth Parameter Assay}

Growth parameters such as lengths of total plant, plumule and radicle length $(\mathrm{cm})$ and root-shoot lengths and ratio were measured with a Vernier calliper post 5 days and 20 days for petri plate and glasshouse tests, respectively.

\subsubsection{Fruit Yield and Quality Parameter assay}

The seedlings derived from primed seeds were cultured as per recommended standard procedures [26] were selected on the basis of randomised block design, performing yield and quality parameter assays, repeating each test five times. The effect of EF-LSE on the yield of cherry tomato plants was estimated by fruit weight. The quality parameters of treated cherry tomato plants were calculated in terms of total soluble solids (TSS) [27], ascorbic acid [28], lycopene [29] and phenol [20] contents.

\subsection{Statistical Analysis}

All the tests were repeated five times. The effect of EF-LSE on seeds was determined by analysis of variance, one-way (ANOVA), and the treatment means were compared by Tukey-family error test $(p<0.05)$ by using Minitab ${ }^{\circledR} 17$ software package (LEAD Technologies Inc., Charlotte, NC, USA).

\section{Results}

\subsection{Seaweed Collection and Identification}

The seaweeds collected from Colachel beach (Figure 1) were subjected to microscopical (Nikon Phase Contrast, Japan) and macroscopical analyses and confirmed to be Ulva flexuosa Wulfen (Ulvaceae), based on morphological characteristics and organoleptic features (Table 1). The seaweed belonging to the green alga, phylum Chlorophyta, is tubular and branched (Figure 2). The cells were observed to be arranged in transverse rows.

Table 1. Organoleptic features of Ulva flexuosa.

\begin{tabular}{cc}
\hline Feature & U. flexuosa Appearance \\
\hline Habitat & Highly cosmopolitan in shallow marine or brackish habitats \\
Shape & Long, filamentous hollow tube thallus \\
Size & $20 \mathrm{~cm}$ \\
Colour & Light green \\
Odour & Foul smelling \\
Taste & Salty \\
Base & Divided \\
Blade & Expanding above the stalk, which ends in a rounded tip \\
\hline
\end{tabular}

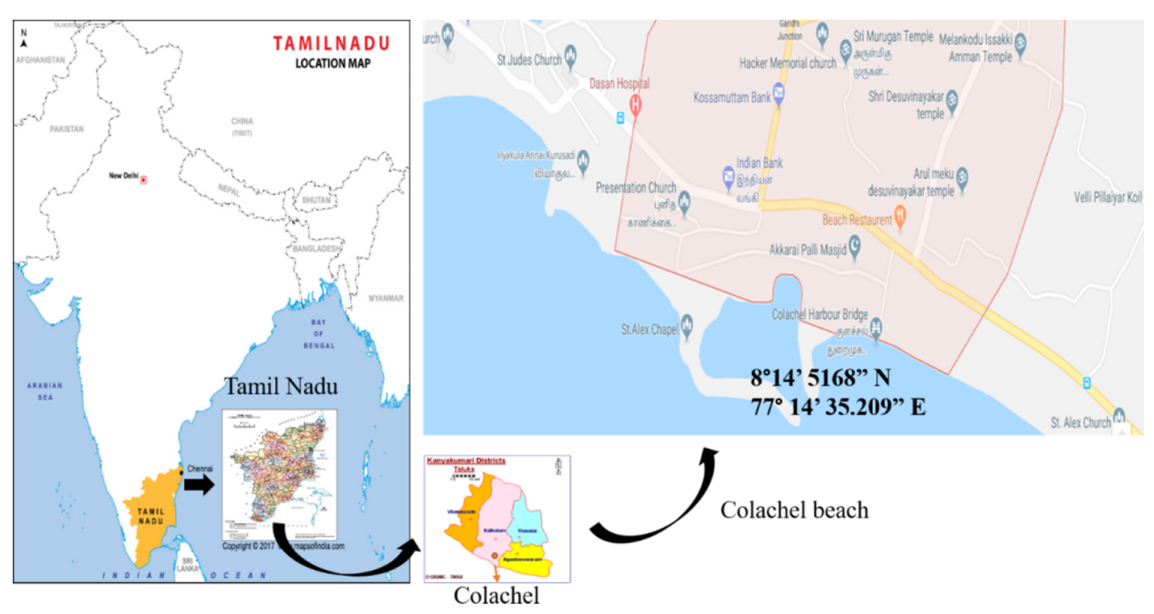

Figure 1. Sample collection site of seaweed from Colachel beach, Kanyakumari, Tamil Nadu, India. 

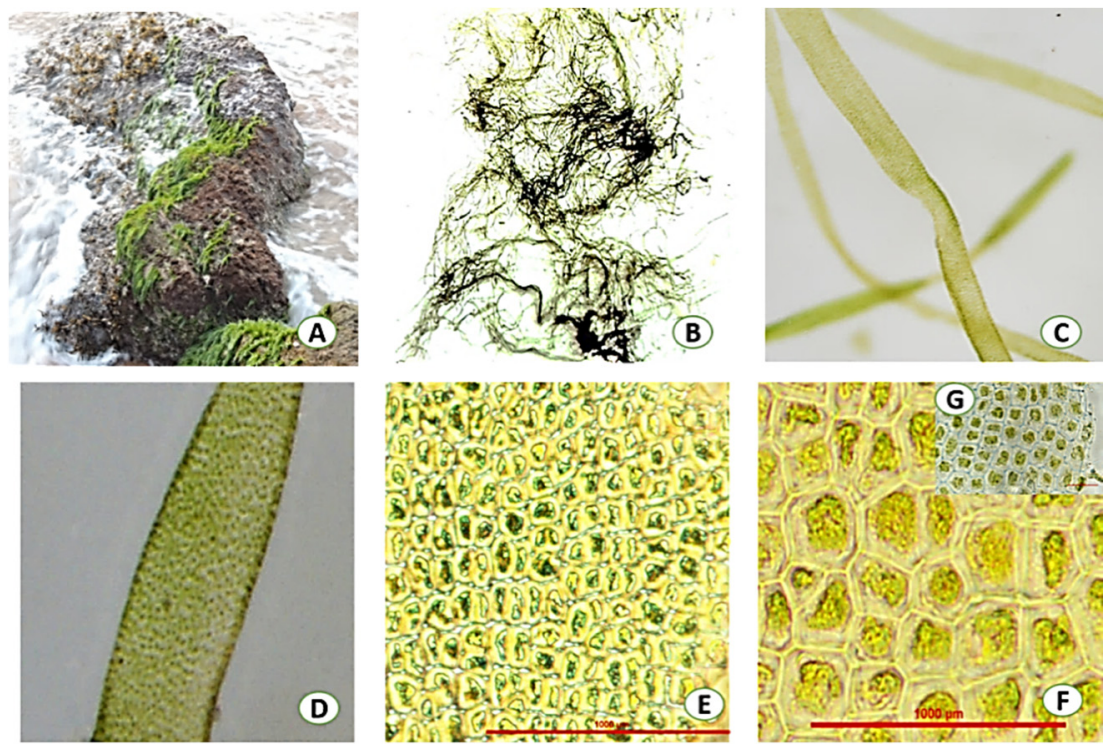

Figure 2. Macroscopic and microscopic images of $U$. flexuosa. ((A): Sample collection site, Colachel beach; (B): U. flexuosa; (C,D): Macroscopic image; Microscopic image of U. flexuosa-(E): 10×; (F): 40× and (G): 100×, showing blue coloured pigments on cell wall).

\subsection{EF-LSE Analyses}

\subsubsection{Physicochemical Screening}

The EF-LSEs appeared as pale greenish yellow in colour. The $\mathrm{pH}$ of the EF-LSEs of doses $20 \%$, $40 \%, 60 \%, 80 \%$ and $100 \%$ was measured and found to be $7.160,7.240,7.34,7.4$ and 7.58 , respectively. The $\mathrm{pH}$ of control was 7 and that of SFS was 4.2. The electrical conductivity (EC) of the respective EF-LSE doses was recorded as $0.96 \mathrm{ds} \mathrm{m}^{-1}, 1.01 \mathrm{ds} \mathrm{m}^{-1}, 1.08 \mathrm{ds} \mathrm{m}^{-1}, 1.54 \mathrm{ds} \mathrm{m}^{-1}$ and $2.8 \mathrm{ds} \mathrm{m}^{-1}$, respectively (Table 2).

Table 2. Physico-chemical properties of LSEs, $\mathrm{pH}$ and EC $\left(\mathrm{dS} \mathrm{m}^{-1}\right)$.

\begin{tabular}{ccc}
\hline Treatments & pH & EC (dS m-1) \\
\hline C & $7.02 \pm 0.004^{\mathrm{a}}$ & - \\
SFS & $4.2 \pm 0.89^{\mathrm{b}}$ & $0.756 \pm 0.03^{\mathrm{a}}$ \\
EF 20\% & $7.160 \pm 0.30^{\mathrm{c}}$ & $1.0180 \pm 0.10^{\mathrm{b}}$ \\
EF 40\% & $7.240 \pm 0.26^{\mathrm{c}}$ & $1.0800 \pm 0.15^{\mathrm{c}}$ \\
\hline EF 60\% & $7.340 \pm 0.21^{\mathrm{cd}}$ & $1.540 \pm 0.36^{\mathrm{c}}$ \\
EF 80\% & $7.400 \pm 0.35^{\mathrm{cd}}$ & $2.880 \pm 0.54^{\mathrm{c}}$ \\
EF 100\% & $7.580 \pm 0.37^{\mathrm{d}}$ & $3.700 \pm 0.57^{\mathrm{d}}$
\end{tabular}

Columns denoted by a different letter are significantly different at $p \leq 0.05$.

\subsubsection{Elemental Composition of EF-LSE Using X-ray-EDS Analysis}

The elemental composition of the seaweed elucidated via EDX analysis (Figure 3) revealed the presence of seven compounds on seaweed cell surface-oxygen, $\mathrm{Na}, \mathrm{Mg}, \mathrm{S}, \mathrm{Cl}, \mathrm{K}$ and $\mathrm{Ca}$. Oxygen was present in higher quantities $(56.25 \%)$, followed by chlorine (13.4\%), sulphur (7.79), and potassium (7.52\%). Magnesium (5.3\%), calcium (4.89\%) and sodium (4.84\%) were also recorded. 


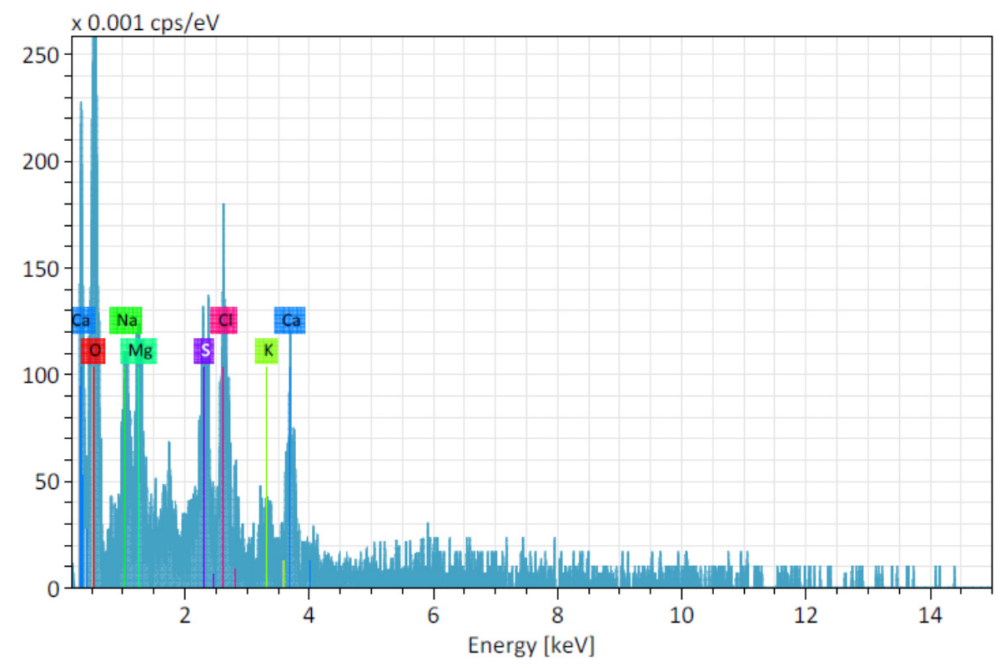

Figure 3. SEM-EDX-Energy Dispersive Spectrum of $U$. flexuosa showing the presence of various elements in their cell wall.

\subsubsection{Phytochemical Screening}

The phytochemical analysis of EF-LSE revealed the presence of carbohydrates, protein, phenols, flavonoids, saponins, tannins and coumarins (Table 3).

Table 3. Phytochemical composition of EF-LSE.

\begin{tabular}{cc}
\hline Phytochemicals & Inference \\
\hline Alkaloids & - \\
Carbohydrates & + \\
Carboxylic acid & - \\
Coumarin & + \\
Flavonoids & + \\
Phenolics & + \\
Protein & + \\
Quinone & - \\
Saponin & + \\
Steroid & - \\
Tannin & + \\
Xanthoprotein & - \\
\hline
\end{tabular}

\subsubsection{Biochemical Screening}

The seaweed examined qualitatively revealed the presence of $1 \mathrm{mg} / \mathrm{g}$ of phenol, $6.1 \%$ protein, and $0.9 \mathrm{mg} / \mathrm{g}$ of total chlorophyll contents.

\subsection{Biostimulant Assays}

The cherry tomato seeds purchased were sown in a greenhouse, according to standard horticultural methods (Figure 4). 

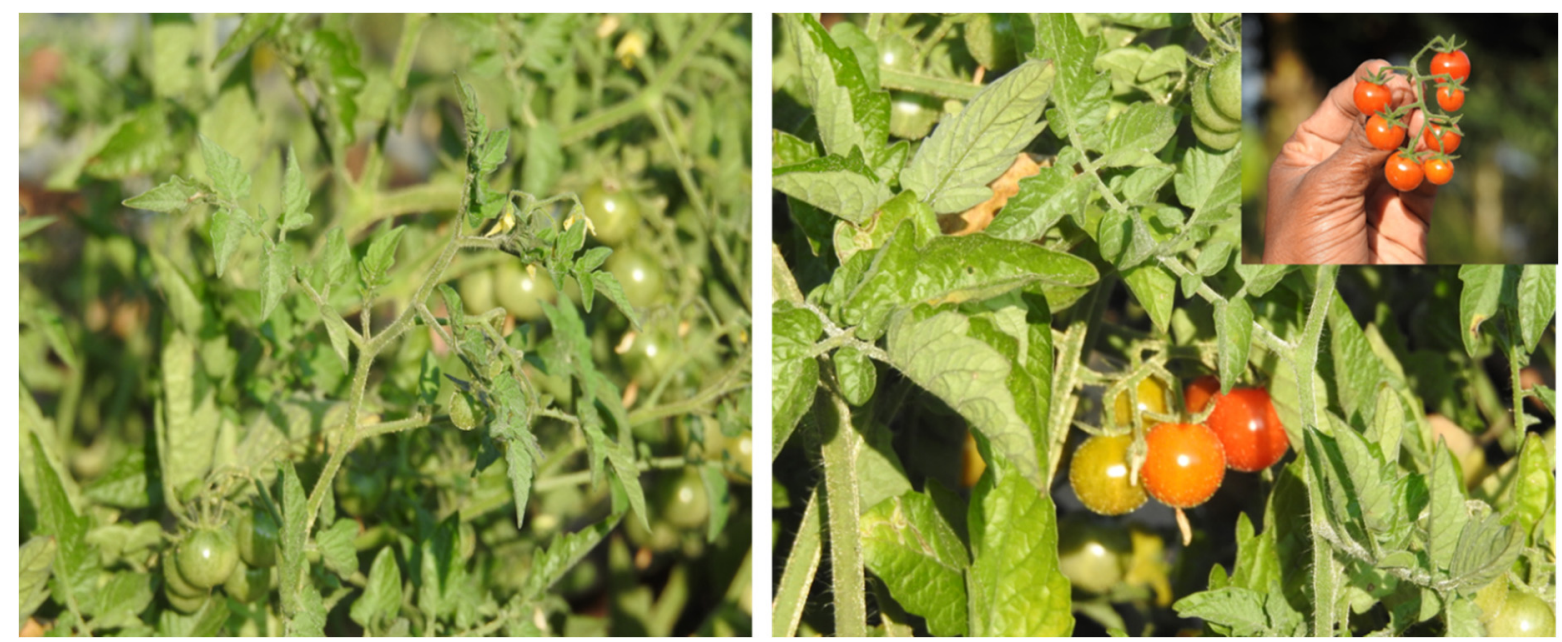

Figure 4. Cherry tomato plants.

\subsubsection{Effect of EF-LSEs on Cherry Tomato Seeds}

Germination of cherry tomato seeds was initiated on day 2 in seeds treated with $80 \%$ and $100 \%$ of EF-LSEs. The EF-LSEs were able to initiate germination of the seedlings in a dose-dependent manner (Figure 5). EF-LSE treated seeds emerged early when compared to the control (Figure 6). In addition, the EF-LSE treated seeds in doses $20 \%, 40 \%, 60 \%, 80 \%$ and $100 \%$ exhibited lower MGT (Figure 7) of 4, $3.4,3,2.6$ and 2.2 days $\left(F_{6,28}=3.23 ; p<0.0001\right)$, respectively, compared with seeds treated with SFS, 4 days $\left(F_{6,28}=3.23 ; p<0.0001\right)$ as well as that of the control, 4.9 days $\left(F_{6,28}=3.23 ; p<0.0001\right)$.

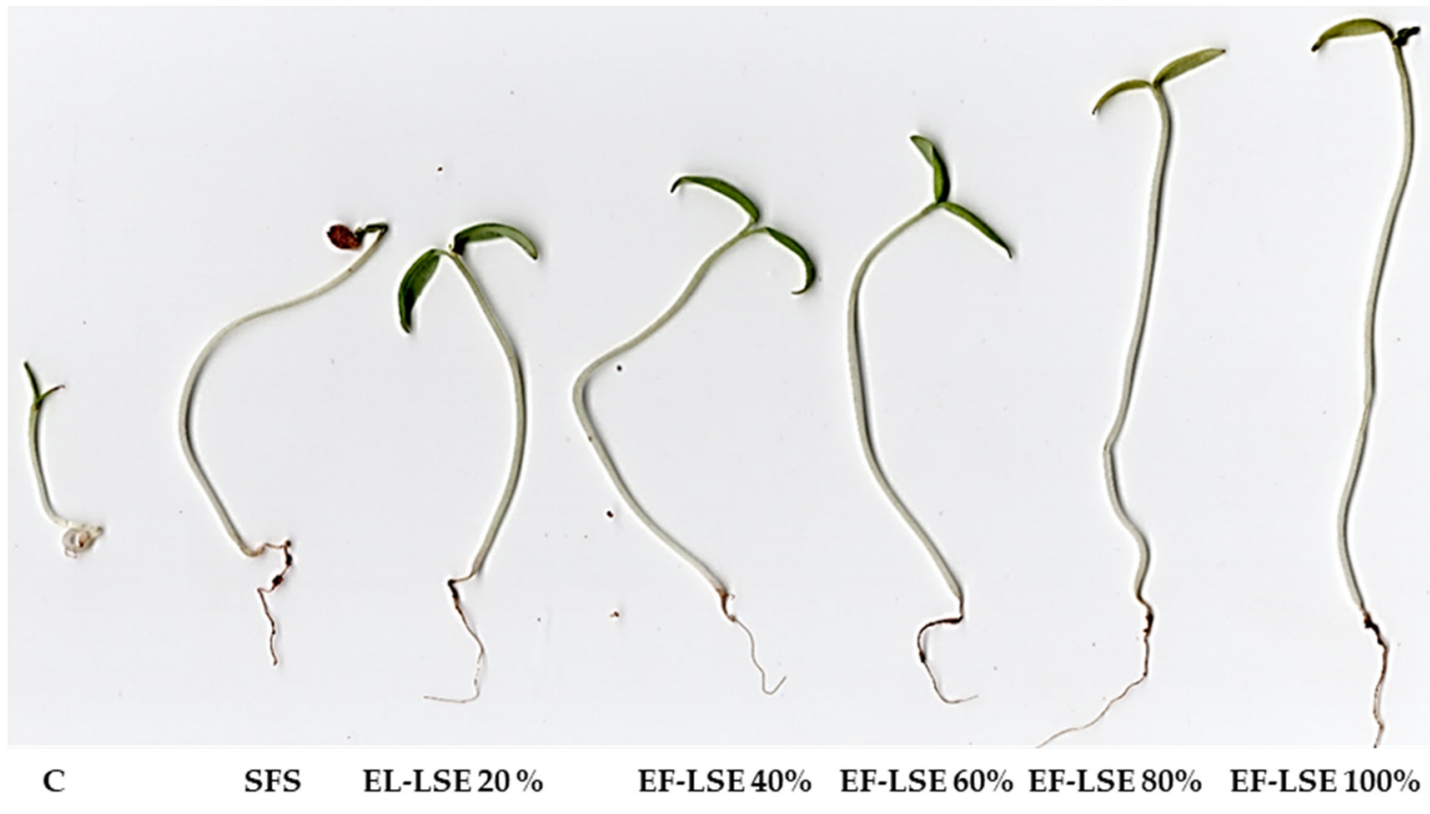

Figure 5. Effect of LSEs on growth of tomato seedlings.

The germination time course for control seeds was longer (Figure 6), taking 86.54, 93.2, 110.64, 116.4 and 125.80 hours $\left(F_{4,20}=30.33 ; p<0.0001\right)$ for $1 \%, 10 \%, 25 \%, 50 \%, 75 \%$ and $100 \%$ of seeds to germinate. Seeds treated with SFS exhibited a time course almost similar to that of control, 85.54, 91.8, $109.34,114.51$ and 125.37 hours $\left(F_{4,20}=30.33 ; p<0.0001\right)$. The germination time course decreased with increase in EF-LSE concentrations. The time taken for emergence of $1 \%$ of seeds decreased from 76.4 
$\left(F_{4,20}=44.77 ; p<0.0001\right)$ to $56.8\left(F_{4,20}=36.81 ; p<0.0001\right)$ and $50.8\left(F_{4,20}=31.39 ; p<0.0001\right)$ hours in seeds treated with $20 \%, 40 \%$ and $60 \% \mathrm{EF}$ - LSEs, respectively.

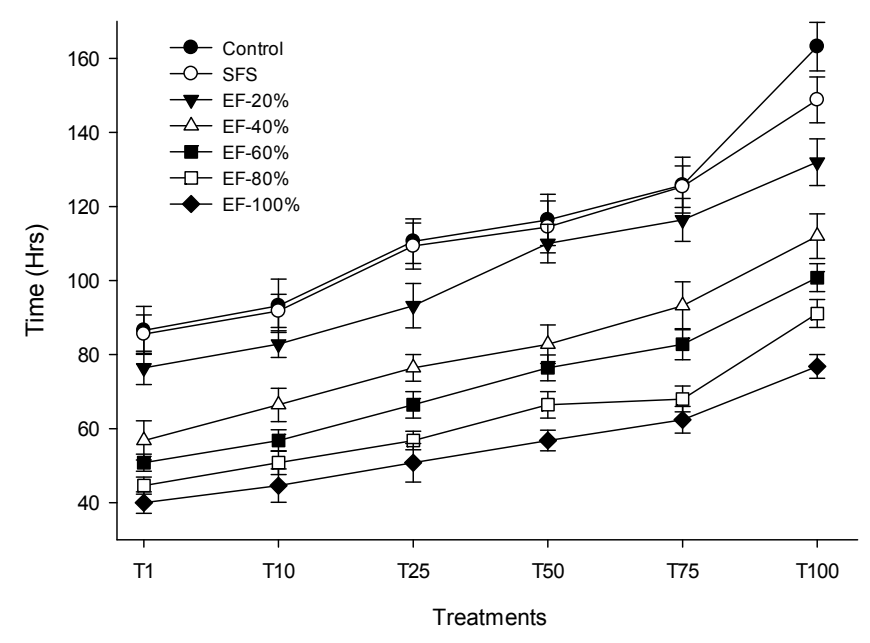

Figure 6. Effect of EF-LSEs on germination of tomato seeds-germination time course.

Similarly, the rate of emergence of seeds increased, resulting in a decreased germination time course, further to $44.6\left(F_{4,20}=15.97 ; p<0.0001\right)$ and $40\left(F_{4,20}=13.66 ; p<0.0001\right)$ hours in $80 \%$ and $100 \%$ EF-LSE treatments, respectively. As a series, the time taken for the emergence of $100 \%$ of seeds in treatment decreased from $163.2\left(F_{4,20}=30.33 ; p<0.0001\right)$ to $148.8\left(F_{4,20}=38.16 ; p<0.0001\right)$ hours in the respective control and SFS treated seeds. The EF-LSE treated seeds took $132\left(\left(F_{4,20}=44.77 ; p<0.0001\right)\right.$, $112.8\left(\left(F_{4,20}=36.81 ; p<0.0001\right), 100.8\left(\left(F_{4,20}=31.39 ; p<0.0001\right), 91.1\left(F_{4,20}=15.97 ; p<0.0001\right)\right.\right.$ and $76.8\left(\left(F_{4,20}=13.66 ; p<0.0001\right)\right.$ hours for $100 \%$ emergence at treatment concentrations of $20 \%, 40 \%$, $60 \%, 80 \%$ and $100 \%$, respectively.

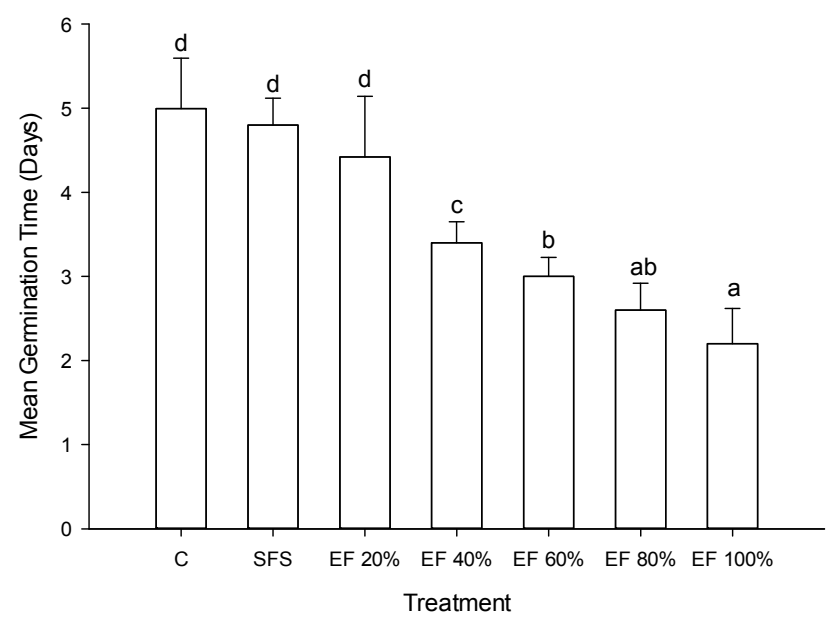

Figure 7. Effect of LSEs on germination of tomato seeds-mean germination time.

The seeds in the petri dishes treated with distilled water exhibited $84.8 \% \mathrm{GP}\left(F_{6,28}=6.4 ; p<0.0001\right)$ at the end of seven days. SFS treated seeds showed a GP of $86.6 \%$ GP $\left(F_{6,28}=6.4 ; p<0.0001\right)$. Seeds treated with $20 \%, 40 \%, 60 \%, 80 \%$ and $100 \%$ EF-LSE, displayed $93 \%, 94 \%, 95 \%, 96 \%$ and $97 \%\left(F_{6,28}=6.4\right.$; $p<0.0001$ ) GP, respectively (Figure 8). The number of days taken for all the EF-LSE treated seeds to germinate also decreased to $5.5,4.7,4.2,3.6$ and 3.2 days $\left(F_{4,20}=13.66 ; p<0.0001\right)$. 


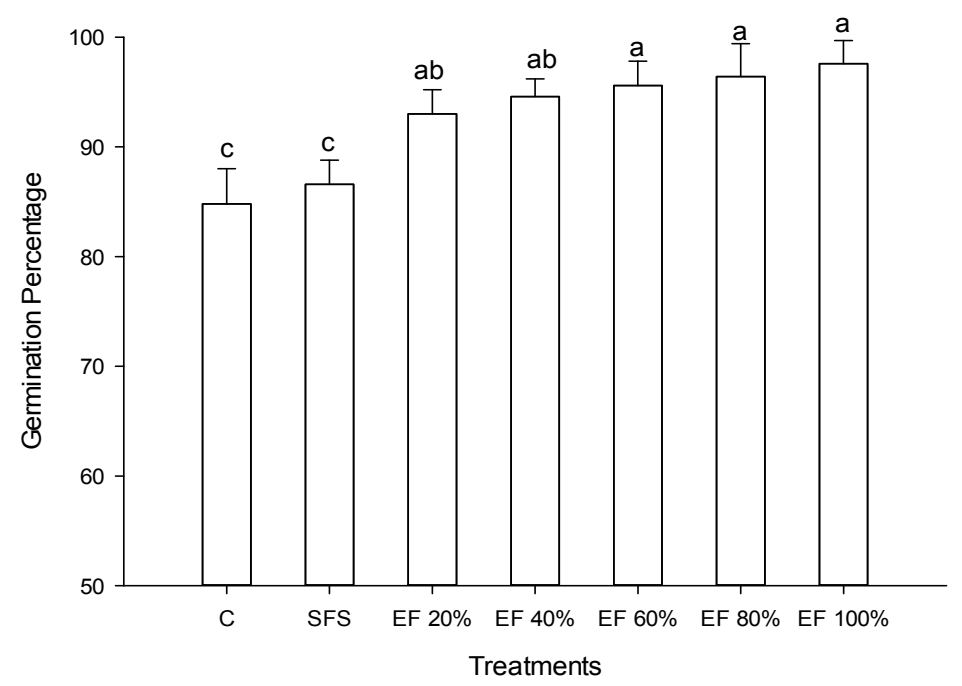

Figure 8. Effect of LSEs on germination percentage of cherry tomato seeds.

The germination energy (Figure 9) of the seeds treated with EF-LSEs were higher, in the range of 55.6, 85.4, 91.6, 94.6 and $97.8\left(F_{6,28}=31.34 ; p<0.0001\right)$ exposed to $20 \%, 40 \%, 60 \%, 80 \%$ and $100 \%$ EF-LSEs, respectively, which was very high in comparison with the control $(10 \%)$ and that of SFS-treated $(20 \%)\left(F_{6,28}=31.34 ; p<0.0001\right)$ seeds.

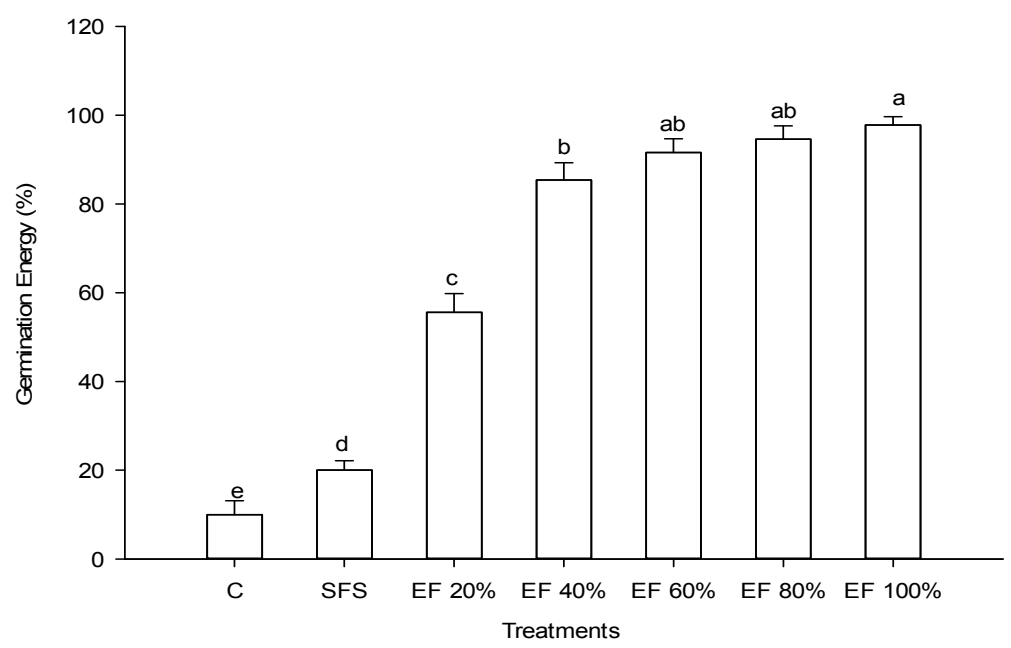

Figure 9. Effect of LSEs on germination energy of cherry tomato seeds.

The seedling vigour index of the control seeds and SFS treated seeds were $457.18\left(F_{6,28}=32.86\right.$; $p<0.0001)$ and $743.75\left(F_{6,28}=32.86 ; p<0.0001\right)$, respectively. However, the SVI of seeds treated with EF-LSEs (Table 4 ) of dosages $20 \%, 40 \%, 60 \%, 80 \%$ and $100 \%$ were enhanced to $1003.59,1047.04,1060.24$, 1236.96 and $1281.31\left(F_{6,28}=32.86 ; p<0.0001\right)$, respectively (Table 4$)$.

The biomass of the cherry tomato seeds was determined after 48 hours of priming. Seeds that were not treated with any extracts unveiled respective dry and wet weights of $0.013 \mathrm{mg}\left(F_{6,28}=32.08\right.$; $p<0.0001)$ and $0.113 \mathrm{mg}\left(F_{6,28}=19.23 ; p<0.0001\right)$. The dry weights of the tomato plants treated with SFS, EF-LSE extracts $-20 \%, 40 \%, 60 \%, 80 \%$ and $100 \%$ were found to be $0.0218 \mathrm{mg}, 0.0262 \mathrm{mg}, 0.0296$ $\mathrm{mg}, 0.0316 \mathrm{mg}, 0.042 \mathrm{mg}$ and $0.0528 \mathrm{mg}\left(F_{6,28}=32.08 ; p<0.0001\right)$ respectively. The wet weights of the tomato plants treated with SFS, EF-LSE extracts-20\%, 40\%, 60\%, 80\% and $100 \%$ were found to be $0.1396 \mathrm{mg}, 0.1434 \mathrm{mg}, 0.144 \mathrm{mg}, 0.152 \mathrm{mg}, 0.2 \mathrm{mg}$ and $0.308 \mathrm{mg}\left(F_{6,28}=19.23 ; p<0.0001\right)$, respectively (Table 4). 
Table 4. Seedling vigour index and biomass (wet and dry weight) of tomato seeds treated with LSEs.

\begin{tabular}{cccc}
\hline \multirow{2}{*}{ Treatments } & \multirow{2}{*}{ Seedling Vigour Index (SVI) } & \multicolumn{2}{c}{ Seed Weight (mg) } \\
\cline { 2 - 4 } & & Wet Weight & Dry Weight \\
\hline C & $457.18 \pm 2.76^{\mathrm{a}}$ & $0.113 \pm 0.007^{\mathrm{a}}$ & $0.013 \pm 0.007^{\mathrm{a}}$ \\
SFS & $743.75 \pm 3.02^{\mathrm{b}}$ & $0.1396 \pm 0.003^{\mathrm{b}}$ & $0.0218 \pm 0.003^{\mathrm{b}}$ \\
Ef $20 \%$ & $1003.59 \pm 1.98^{\mathrm{c}}$ & $0.1434 \pm 0.009^{\mathrm{c}}$ & $0.0262 \pm 0.009^{\mathrm{c}}$ \\
Ef $40 \%$ & $1047.04 \pm 3.01^{\mathrm{d}}$ & $0.144 \pm 0.005^{\mathrm{c}}$ & $0.0296 \pm 0.001^{\mathrm{d}}$ \\
Ef $60 \%$ & $1060.24 \pm 2.45^{\mathrm{e}}$ & $0.152 \pm 0.003^{\mathrm{d}}$ & $0.0316 \pm 0.003^{\mathrm{e}}$ \\
Ef $80 \%$ & $1236.96 \pm 1.43^{\mathrm{f}}$ & $0.2 \pm 0.003^{\mathrm{e}}$ & $0.042 \pm 0.003^{\mathrm{f}}$ \\
Ef $100 \%$ & $1281.31 \pm 2.65^{\mathrm{g}}$ & $0.308 \pm 0.002^{\mathrm{f}}$ & $0.0528 \pm 0.002^{\mathrm{g}}$ \\
\hline
\end{tabular}

Columns denoted by a different letter are significantly different at $p \leq 0.05$.

The moisture content of the dry seeds was 7.8\%, which increased after six hours in all SFS and EF-LSE treatments. The moisture content of control seeds increased to $8 \%, 9 \%, 9.4 \%, 9.7 \%$ and $9.9 \%$ at $6,12,24,36$ and 48 hours. A comparatively higher imbibition occurred in EF-LSE treated seeds, with a minimum imbibition of $8.5 \%$ and a maximum of 9.5 after six hours, in $20 \%$ and $100 \%$ primed seeds (Figure 10).

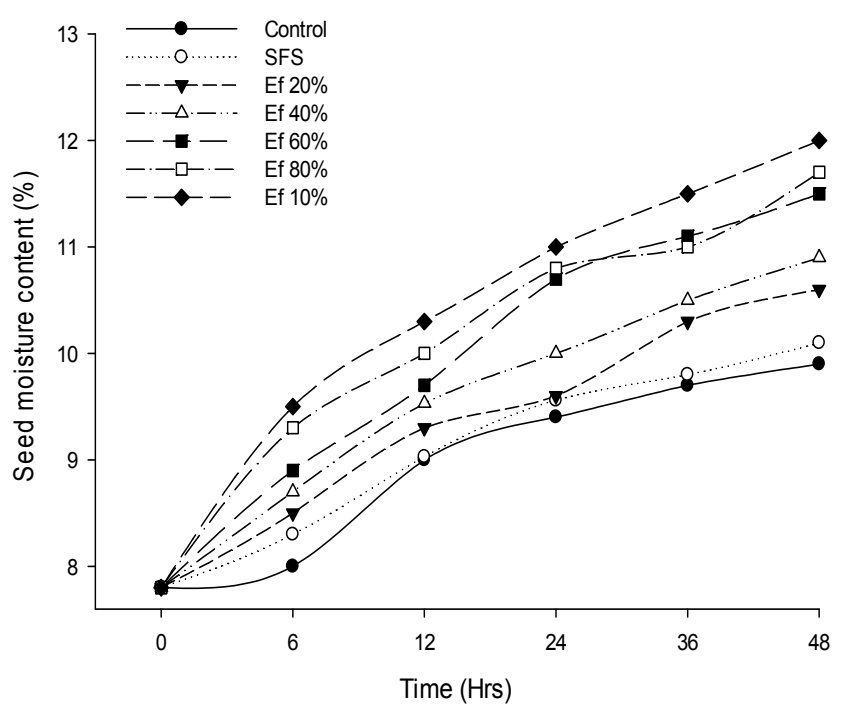

Figure 10. Effect of EF-LSEs on seed imbibition capabilities of tomato seeds.

\subsubsection{Effect of EF-LSEs on Growth Parameters of Cherry Tomato}

The effect of EF-LSEs on the growth of tomato seedlings tested exhibited significant differences in total seedling length (Figure 11), radicle, and plumule length (Figure 12).

The height of the tomato seedlings at the end of five days was $5.4 \mathrm{~cm}\left(F_{6,28}=30.98 ; p<0.005\right)$, with radicle and plumule lengths of $4 \mathrm{~cm}\left(F_{6,28}=42.16 ; p<0.005\right)$ and $3 \mathrm{~cm}\left(F_{6,28}=42.94 ; p<0.005\right)$, respectively (Figure 12$)$, with 1.26 radicle: plumule ratio $\left(F_{5,24}=32.20, p<0.005\right)$ (Figure 13 ).

The SFS was able to induce the seedling length to $8.6 \mathrm{~cm}\left(F_{6,28}=30.98 ; p<0.005\right)$ with a corresponding radicle and plumule lengths, ratio of $4.2\left(F_{6,28}=42.16 ; p<0.005\right)$ and $3.72 \mathrm{~cm}$ $\left(F_{6,28}=42.94 ; p<0.005\right), 1.36\left(F_{5,24}=32.20, p<0.005\right)$, respectively. The EF-LSEs had a positive effect in stimulating the seedling height and their respective radicle and plumule lengths to $10.8 \mathrm{~cm}$ $\left(F_{6,28}=30.98 ; p<0.005\right), 5.12 \mathrm{~cm}\left(F_{6,28}=42.16 ; p<0.005\right)$ and $4.12 \mathrm{~cm}\left(F_{6,28}=42.94 ; p<0.005\right)$, respectively, at $20 \%$ concentration, exhibiting radicle: plumule ratio of $1.36\left(F_{5,24}=32.20, p<0.005\right)$. 


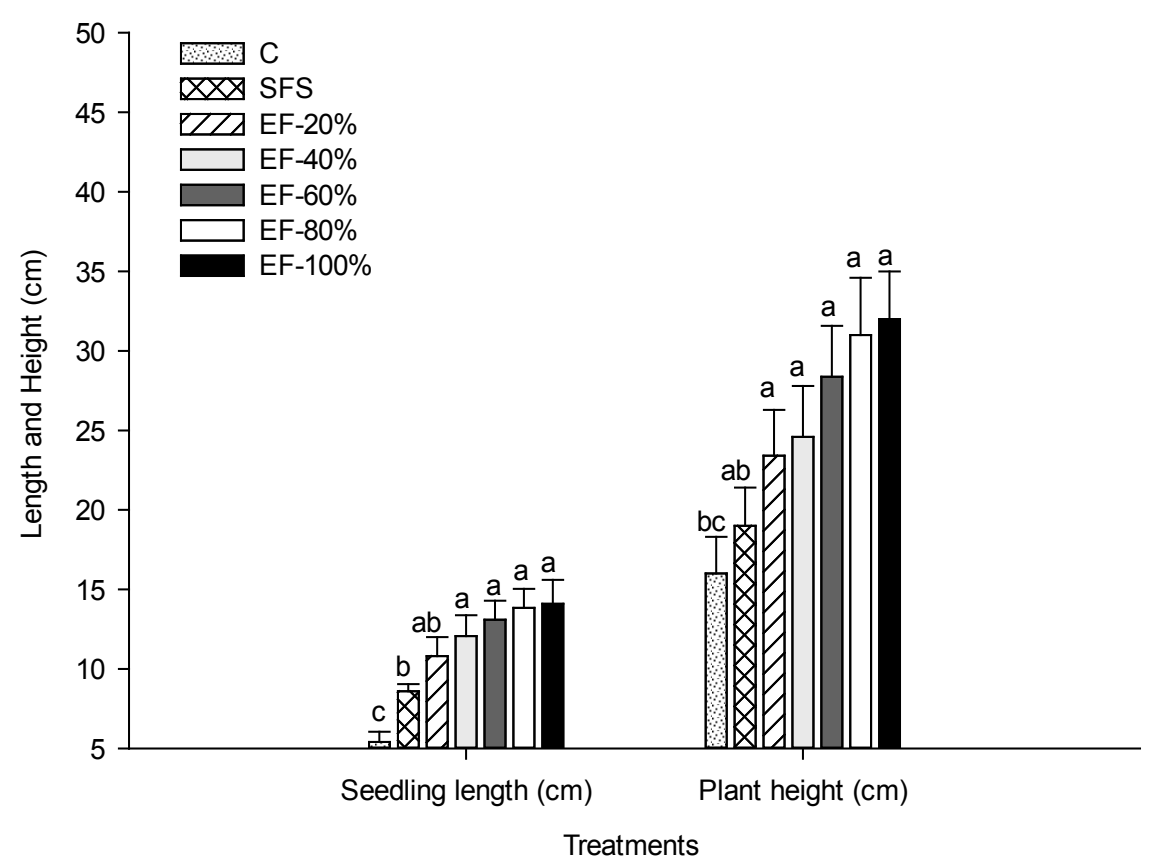

Figure 11. Effect of EF-LSEs on growth parameters of tomato seedling and plant height.

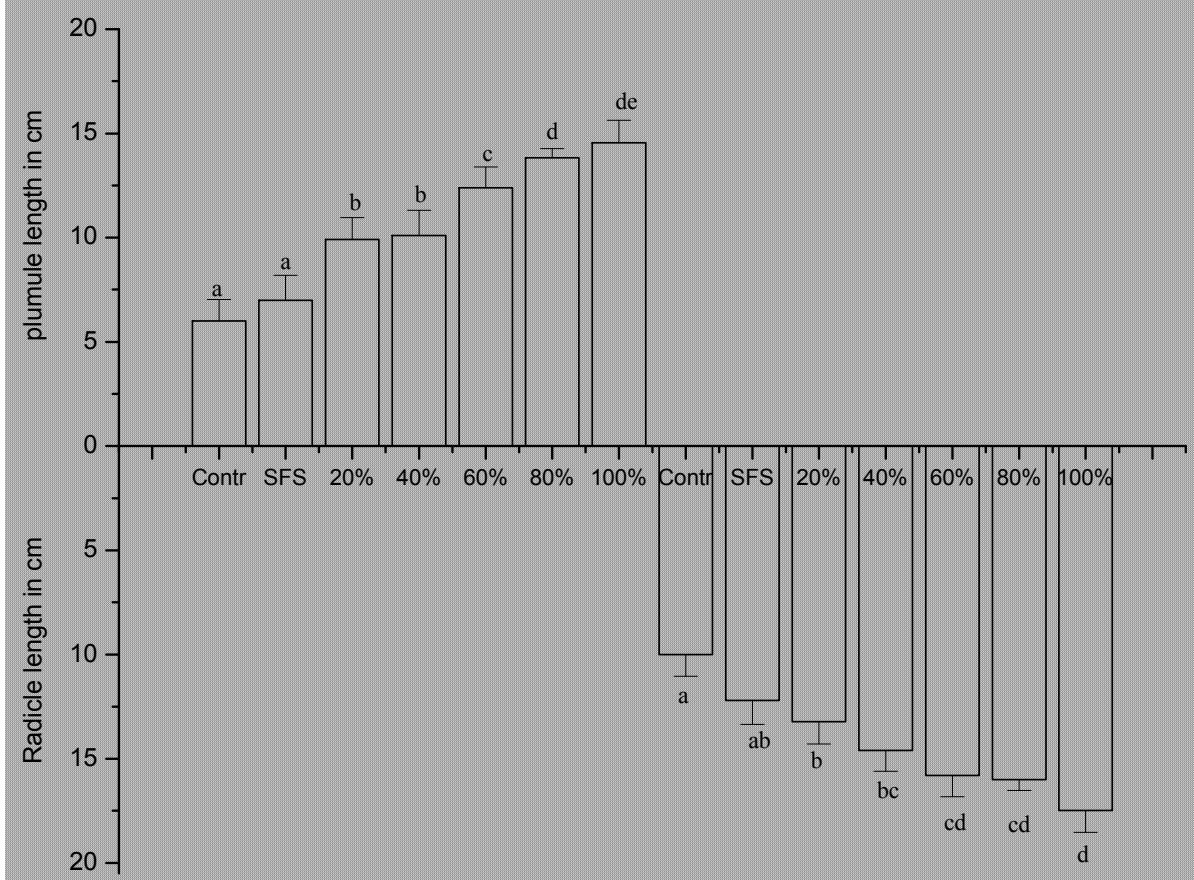

Figure 12. Effect of EF-LSEs on growth parameters of tomato seeds (plumule-radicle length).

The EF-LSEs had a positive effect in stimulating seedling height and their respective radicle and plumule lengths to $10.8 \mathrm{~cm}\left(F_{6,28}=30.98 ; p<0.005\right), 5.12 \mathrm{~cm}\left(F_{6,28}=42.16 ; p<0.005\right)$ and $4.12 \mathrm{~cm}$ $\left(F_{6,28}=42.94 ; p<0.005\right)$, respectively, at $20 \%$ concentration, exhibiting radicle: plumule ratio of $1.36 \mathrm{~cm}$ $\left(F_{5,24}=32.20, p<0.005\right)$. Similarly, the $40 \%$ EF-LSE treated seeds exhibited respective seedling height, radicle and plumule lengths, radicle: plumule ratio of $12.07 \mathrm{~cm}\left(F_{6,28}=30.98 ; p<0.005\right), 5.72 \mathrm{~cm}$ $\left(F_{6,28}=42.16 ; p<0.005\right)$ and $5 \mathrm{~cm}\left(F_{6,28}=42.94 ; p<0.005\right)$ and $1.59\left(F_{5,24}=32.20, p<0.005\right)$. Likewise $60 \%$ and $80 \%$ EF-LSE treated seeds were observed with seedling lengths of $13.09 \mathrm{~cm}$ and $13.84 \mathrm{~cm}$ $\left(F_{6,28}=30.98 ; p<0.005\right)$, with corresponding radicle and plumule lengths of $7.6 \mathrm{~cm}\left(F_{6,28}=42.16\right.$; $p<0.005)$ and $5.8 \mathrm{~cm}\left(F_{6,28}=42.94 ; p<0.005\right)$ as well as $8.2 \mathrm{~cm}\left(F_{6,28}=42.16 ; p<0.005\right)$ and $6.4 \mathrm{~cm}$ 
$\left(F_{6,28}=42.94 ; p<0.005\right)$ besides the radicle: plumule ratios of 1.76 and $1.9\left(F_{5,24}=32.20, P<0.005\right)$, respectively. The seeds treated with $100 \%$ EF-LSE exhibited the highest seedling length of $14.1 \mathrm{~cm}$ $\left(F_{6,28}=30.98 ; p<0.005\right)$ with radicle and plumule lengths of $8.2 \mathrm{~cm}\left(F_{6,28}=42.16 ; p<0.005\right)$ and $6.4 \mathrm{~cm}$ $\left(F_{6,28}=42.94 ; p<0.005\right)$, respectively. They revealed a radicle: plumule ratio of $2.04\left(F_{5,24}=32.20\right.$, $p<0.005)$.

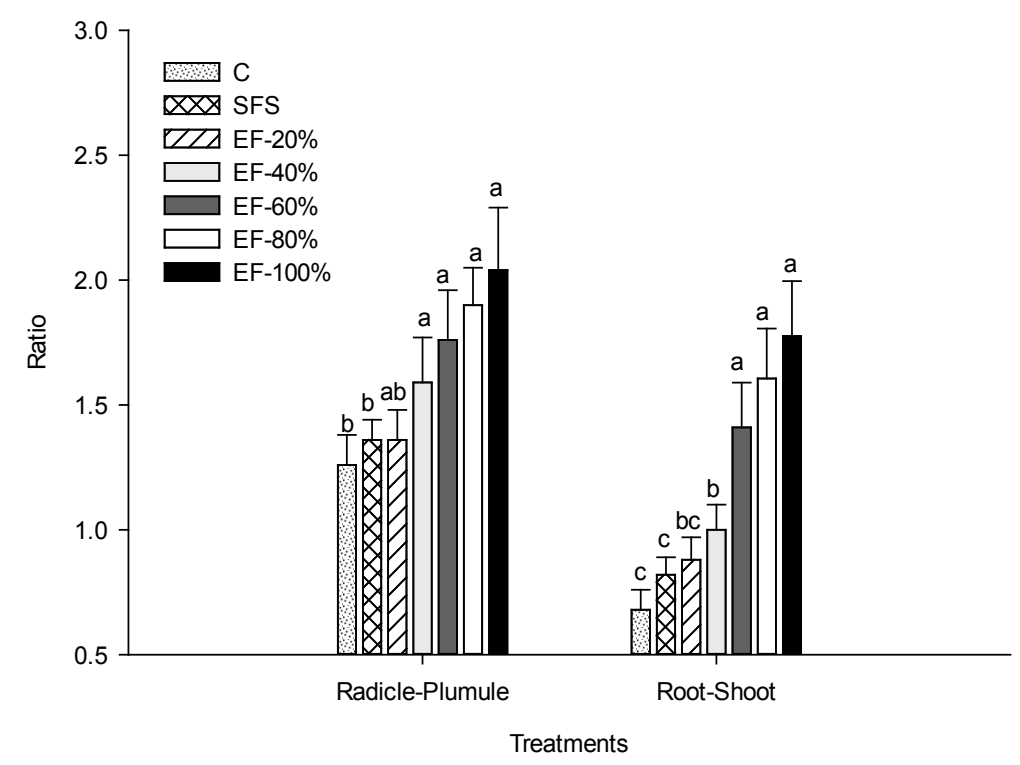

Figure 13. Radicle-plumule as well as root-shoot ratio of tomato seedlings.

The effect of EF-LSEs on the growth of tomato plants tested exhibited significant differences in total plant height (Figure 11), root, and shoot lengths (Figure 14).

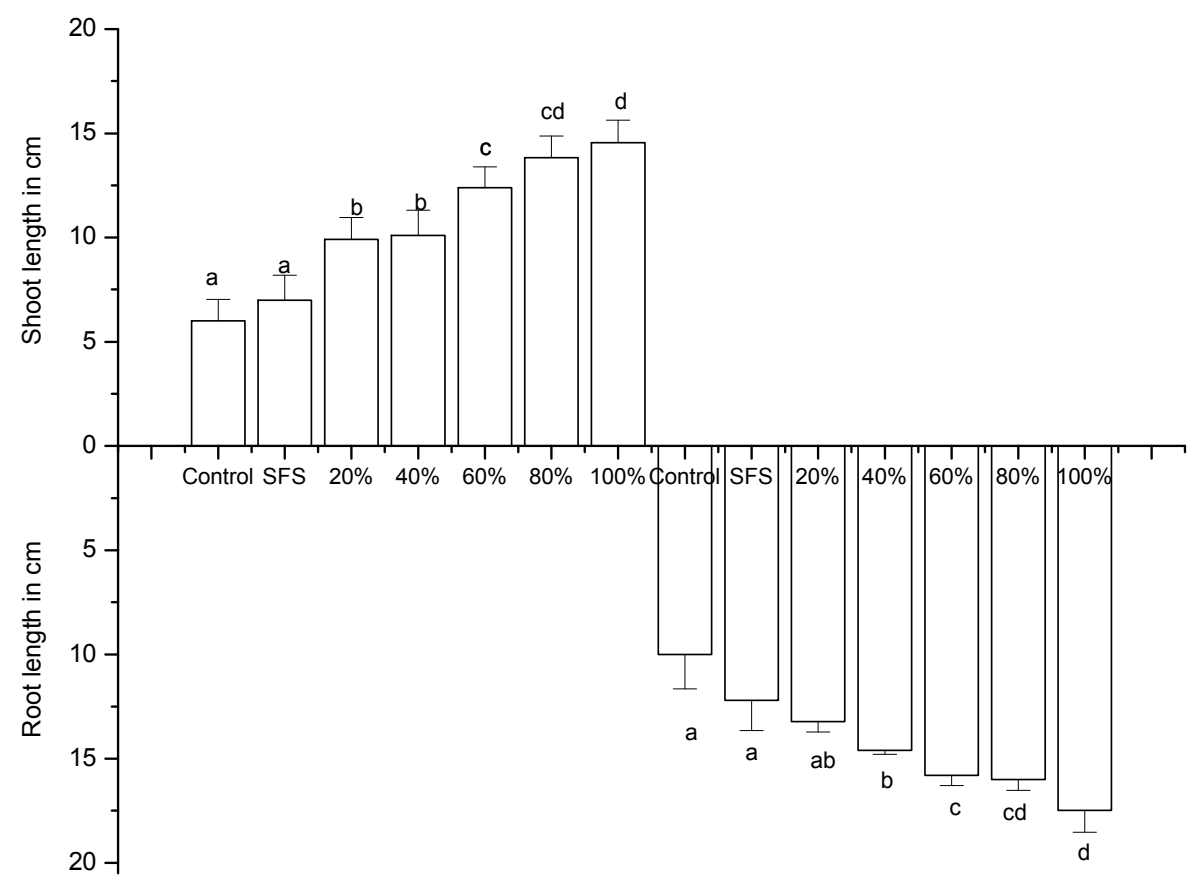

Figure 14. Effect of EF-LSE on root-shoot lengths of tomato plants. 
The height of the tomato plant at the end of 20 days was $16 \mathrm{~cm}\left(F_{6,28}=40.45 ; p<0.003\right)$, with root and shoot lengths of $6 \mathrm{~cm}\left(F_{6,28}=30.87 ; p<0.005\right)$ and $10 \mathrm{~cm}\left(F_{5,24}=32.40 ; p<0.005\right)$, respectively, with 0.68 root: shoot ratio $\left(F_{6,28}=18.76 ; p<0.000\right)$. The SFS was able to induce plant height to $19 \mathrm{~cm}$ $\left(F_{6,28}=40.45 ; p<0.003\right)$ with a corresponding root, shoot lengths and ratio of $7 \mathrm{~cm}\left(F_{6,28}=30.87\right.$; $p<0.005)$ and $12.2 \mathrm{~cm}\left(F_{5,24}=32.40 ; p<0.005\right)$, and $0.82\left(F_{6,28}=18.76 ; p<0.00001\right)$, respectively. The EF-LSEs had a positive effect in stimulating tomato plant height and their respective root and shoot lengths to $23.4 \mathrm{~cm}\left(F_{6,28}=40.45 ; p<0.003\right), 9.9 \mathrm{~cm}\left(F_{6,28}=30.87 ; p<0.005\right)$ and $13.22 \mathrm{~cm}\left(F_{5,24}=32.40\right.$; $p<0.005)$, respectively, at $20 \%$ concentration, exhibiting root: shoot ratio $0.88\left(F_{6,28}=18.76 ; p<0.0001\right)$. Similarly, the $40 \%$ EF-LSE treated seeds exhibited respective plant height, root and shoot lengths, root: shoot of $24.6 \mathrm{~cm}\left(F_{6,28}=40.45 ; p<0.003\right), 10.1 \mathrm{~cm}\left(F_{6,28}=30.87 ; p<0.005\right)$ and $14.6 \mathrm{~cm}\left(F_{5,24}=32.40\right.$; $p<0.005)$ and $1\left(F_{6,28}=18.76 ; p<0.000\right)$. Likewise, $60 \%$ and $80 \%$ EF-LSE treated seeds were observed with total plant heights of $28.38 \mathrm{~cm}$ and $31 \mathrm{~cm}\left(F_{6,28}=40.45 ; p<0.003\right)$, with corresponding root and shoot lengths of $12.38 \mathrm{~cm}\left(F_{6,28}=30.87 ; p<0.005\right)$ and $15.8 \mathrm{~cm}\left(F_{5,24}=32.40 ; p<0.005\right)$ as well as $13.82 \mathrm{~cm}\left(F_{6,28}=30.87 ; p<0.005\right)$ and $16 \mathrm{~cm}\left(F_{5,24}=32.40 ; p<0.005\right)$ besides the root: shoot ratios of 1.41 and $1.606\left(F_{6,28}=18.76 ; p<0.0001\right)$, respectively (Figure 13$)$. The seeds treated with $100 \%$ EF-LSE exhibited the highest plant height of $32 \mathrm{~cm}\left(F_{6,28}=40.45 ; p<0.003\right)$ with root and shoot lengths of $14.54 \mathrm{~cm}\left(F_{6,28}=30.87 ; p<0.005\right)$ and $17.48 \mathrm{~cm}\left(F_{5,24}=32.40 ; p<0.005\right)$, respectively. They revealed a root: shoot ratio of $1.776\left(F_{6,28}=18.76 ; p<0.0001\right)$.

\subsubsection{Effect of EF-LSEs on Fruit Quality Parameters of Cherry Tomato}

The treated plants displayed a yield of $2.617 \mathrm{~kg} / \mathrm{plant}$ compared with that of the control: $1.07 \mathrm{~kg} /$ plant $\left(F_{1,8}=40.92 ; p<0.0001\right)$. Further, the quality parameters analyses revealed the presence of increased amounts of 6.54 (Brix) TSS, $13.2 \mathrm{mg} / 100 \mathrm{~g}$ FM ascorbic acid, $88.45 \mu^{-g^{-1}} \mathrm{FM}$ lycopene and $7.26 \mathrm{mg} \mathrm{g}^{-1} \mathrm{DM}$ phenol contents, compared with that of the control, which recorded 5.2 (Brix) TSS $\left(F_{1,8}=57.1 ; p<0.002\right), 10.48 \mathrm{mg} / 100 \mathrm{~g}$ FM ascorbic acid $\left(F_{1,8}=53.52 ; p<0.0001\right), 55.206 \mu \mathrm{g}$ $\mathrm{g}^{-1}$ FM lycopene $\left(F_{1,8}=61 ; p<0.003\right)$ and $5.72 \mathrm{mg} \mathrm{g}^{-1} \mathrm{DM}$ phenol $\left(F_{1,8}=47.8 ; p<0.0001\right)$ contents (Table 5).

Table 5. Yield, TSS, Ascorbic acid, lycopene and phenol contents of treated cherry tomato fruits.

\begin{tabular}{|c|c|c|}
\hline Parameters & $\mathrm{C}$ & EF-LSE Treated \\
\hline Yield (kg/plant) & $1.07 \pm 0.96^{\mathrm{a}}$ & $2.617 \pm 1.02^{b}$ \\
\hline TSS (Brix) & $5.2 \pm 1.1^{\mathrm{a}}$ & $6.54 \pm 1.07^{b}$ \\
\hline Ascorbic acid (mg/100g FM) & $10.48 \pm 1.8^{\mathrm{a}}$ & $13.2 \pm 1.5^{b}$ \\
\hline Lycopene ( $\left.\mu \mathrm{g} \mathrm{g}^{-1} \mathrm{FM}\right)$ & $55.206 \pm 3.9^{a}$ & $88.45 \pm 4.3^{b}$ \\
\hline Phenol (mg g $\left.{ }^{-1} \mathrm{DM}\right)$ & $5.72 \pm 1.47^{\mathrm{a}}$ & $7.26 \pm 1.15^{b}$ \\
\hline
\end{tabular}

Rows denoted by a different letter are significantly different at $p \leq 0.05$.

\section{Discussion}

The indiscriminate application of fertilizers has not only intoxicated the environment, but also lost their efficiency. Alternative naturally benign bases of fertilizers, sourced from biological sources such as plants, animals and micro-organisms, have paved the way for the practice of "organic farming". Many eco-friendly bioactive compounds from seaweeds have been widely used in the agricultural field as plant growth promoters. Seaweeds are reported for their copious amounts of novel as well as assorted range of marine secondary metabolites [30]. Global population growth has seen leaps and bounds in the recent years, posing food insecurity [31]. With the foremost necessity of augmentation of crop production, farmers are in stress to improve yields of agriculturally important crops. As an imperative crop, the germination capability of tomato seed is valued to be around $70 \%$. Seed emergence is mainly prejudiced by the equipoise, flanked by the growth skills of the embryo, in addition to the mechanical resistance of the endosperm, which should be debilitated for germination [32]. Seaweeds are being sought out as potential enhancers of crop growth and yield and are replacing chemical 
fertilizers owing to higher efficiencies, broader action range, eco-friendly nature, and cost-effective feature. Seaweeds, reported with outstanding plant growth promoting potentials, increased plant height, root as well as shoot lengths, consequently, are designated as plant growth biostimulants, as reviewed by Khan et al. [7] and Craigie [33] As a crucial and initial plant growth activity, the evaluation of a seed's germination and associated parameters can help in determining the rate of a crop success, in terms of yield and economy [34]. As contemplation, the current investigation was performed to determine the plant growth stimulant activities of green seaweed $U$. flexuosa (Chlorophyceae).

As the germination of a seed counts on various physical aspects, together with nutrient composition [12], preliminary tests of the extracts were performed by analyzing the $\mathrm{pH}$ and electrical conductivity (EC) of the extracts. The nutrient content of a solution, in terms of salts and electrolyte concentration can be determined by measuring their EC. The EF-LSE of $U$. flexuosa was found to possess a neutral $\mathrm{pH}$ and an optimum EC that indicates the presence of salts, for instance, boron, zinc, magnesium, calcium and other essential plant nutrients in a nutritive solution [35]. Higher rates of EC of nutrient or fertilizer solutions are proven with the stimulation of favourable agronomic traits, such as increase in nutritional quality, colour gradient and quality of tomato fruits [36,37]. However, solutions outside the optimum EC had an inhibitory effect on plant growth activities [38]. A nutrient solution within optimum EC was found optimal for the growth stimulation of lettuce in glasshouse conditions [39]. Henceforth, the EF-LSEs were designated as ideal to be tested for biostimulant potential by means of seed priming.

Additional experiments were carried out to determine the phytochemical as well as the elemental composition of the EF-LSEs. A preliminary phytochemical screening of the EF-LSE was done, which exposed the existence of more than a few compounds, such as carbohydrates, protein, phenols, flavonoids, saponins, tannins, and coumarins. Carbohydrates from different seaweeds were found to act as growth promoters of several crops such as tomato, soybean, duckweed and mung bean [40-42]. Proteins from seaweeds are recorded for their enhanced plant biostimulant activities in mung bean [43], and cherry tomato plants [44]. Proteins help plants to alleviate stress and increase their tolerance levels against abiotic stress like heat, cold, salt and even heavy metals [45].

Seaweeds are rich in phenolic compounds with varied bioactive properties [46,47]. Rajauria et al. [48] identified and characterized eight phenolic compounds from brown Irish seaweed Himanthalia elongate, which exhibited strong antioxidant activities. Chanthini et al. [6] correlated the levels of phenolic compound concentration with their antifungal potential. U. flexuosa had a considerate amount of phenols $(1 \mathrm{mg} / \mathrm{g}$ of dry weight). Farasat et al. [49] detected higher phenolics as well as flavonoid levels from U. flexuosa and other edible green seaweeds. Besides, Ascophyllun nodosum extracts were able to increase the levels of phenols and flavonoids together, post application [50]. Saponins showcase a wide array of biological activities that play a pivotal role in plant growth as well as defense [51]. Coumarins also play a crucial part in plant development. These compounds have been proven with plant growth promotion capabilities alone and also in combination with phytohormones in faba bean [52]. Besides, the coumarin compounds were able to stimulate seed germination and seedling growth of wheat and sorghum seeds at optimum concentrations [53].

Tuhy et al. [54] testified that plant biomass surged by treatment with seaweed-derived micronutrients. The composition and functioning, together with the yield of all the plants, are reliant on their chlorophyll contents [55]. The chlorophyll content of $U$. flexuosa ranged up to $0.9 \mathrm{mg} / \mathrm{g}$, which is relatively high among several other green seaweeds. This was also in agreement with the results published by Rathod [56]. The elemental composition performed revealed the presence of seven elements $(\mathrm{O}, \mathrm{Na}, \mathrm{Mg}, \mathrm{S}, \mathrm{Cl}, \mathrm{K}$ and $\mathrm{Ca}$ ) present on cell wall surface. The seaweed was $56.25 \% \mathrm{w} / \mathrm{v}$ of oxygen and along with high phenol content may be regarded as excellent candidates of antioxidizing agents [57]. Plant growth promoting elements such as sodium and potassium present in the cell wall of the seaweed makes them appropriate biofertilizers, besides a broad-spectrum of applications in the agricultural sector [58]. Several other mineral compounds such as chlorine, magnesium and calcium that are critical plant micronutrients are extant in the cell surface. 
Tomato seeds treated with EF-LSEs displayed a positive response with respect to early germination, mean germination time, germination percentage, energy as well as better seed vigour index. Seed priming treatments achieved with quite a few plant derivatives such as plant hormones have been operational in the enhancement of seed germination of Angelica glauca, a threatened medicinal herb [59] as well as endive and chicory [60]. Seaweed extracts have been proven to show development enhancing properties on plant as well as seeds of various plants [61,62]. Also, priming seeds promoted early emergence of brinjal and tomato seeds compared with un-primed [63].

The seeds primed with EF-LSEs of $U$. flexuosa was analysed in different concentrations, comparing with the standard SFS solution and the control. The EF-LSE treated seeds displayed an increased germination percentage, exhibiting a lower mean germination time (MGT), taking only 2.2 days to emerge. Codium tomentosum, a green seaweed extract-treated aubergine seeds displayed lower MGT [64]. The potential of EF-LSEs to stimulate seed germination was reported long back in ornamental plants [65], green Chilies and Turnip [66]. Kavipriya et al. [67] also reported that priming of green gram seed with different seaweed extracts such as Ulva lactuca and Caulerpa scalpelliformis induced faster seed germination. Rapid seed emergence was recorded by priming the red gram seeds with the extracts of Sargassum myriocystum [68]. Furthermore, the positive effects of seaweed on the germination of green [69] and black gram [70] were also noted.

The comparative increase in seed emergence is correlated with seed eminence that is appeared to be augmented by the treatment of EF-LSEs. In addition, Amabika and Sujatha [68] proved that seed quality can be assessed by determining their seedling vigour index. Higher SVI of EF-LSE treated seeds implies an upliftment in seed quality. This was also evident from the results of other parameters of EF-LSE treated seeds, exhibiting higher seedling-plant height, radicle-root, as well as plumule-shoot lengths and dry-wet weight, in comparison with the control. Similar results of increased SVI from seed priming with EF-LSEs of $U$. lactuca, $U$. reticulata, Padina pavonica, $S$. johnstonii were correlated with that of increased seed germination and growth rates of brinjal and tomato, along with chilli [63].

As the primary developmental plant growth phase, the radicle and plumule are of prominent importance to determine the foundation of a plant. Seeds with an eminent radicle and plumule grow hastily, besides having an amplified competence [71]. Longer radicle lengths are also indicators of greater plant establishment efficiency. Seeds that produce shortened radicle-plumule might have issues in nutrient conduction to the embryo [72]. The EF-LSE primed seeds exhibited higher lengths of radicle and plumule, which improved with higher concentrations. EF-LSEs of seaweeds, S. wightii and U. lactuca, were demonstrated in their latent seed germination, besides plant growth promotion capabilities [73,74]. Similar increase of radicle-plumule lengths of tomato seeds was observed with the EF-LSEs of C. sertularioides and S. liebmannii [75].

The growth enhancement displayed by the EF-LSE primed seeds is owed to the occurrence of essential plant macro- and micro-nutrients, in addition to phytohormones. Di Filippo-Herrera et al. [76] reported the biostimulant activity of red seaweeds (Acanthophora spicifera, Gelidium robustum, and Gracilaria parvispora) and brown seaweeds (Macrocystis pyrifera, Sargassum horridum and Ecklonia arborea) primed on seeds of mung bean, which is primarily due to their nutritional and hormonal constituents. The fact that seaweeds stimulate plant growth has been documented by various researchers worldwide [77,78].

Similarly, EF-LSEs were earmarked for plant growth promotion by amplifying the growth of root and shoot of the tomato seeds, thereby displaying increased heights, compared to the control. Plant height was higher compared with seeds treated with SFS. Seaweed-treated seeds exhibiting higher root shoot lengths and ratio were previously reported in many studies $[74,79,80]$. Unlike the plant assessment results, comparatively developed shoot lengths remained. This suggests that the distribution of photosynthates and other compounds that aid in plant growth has shifted towards the shoot or increased in the above ground area. This could pave the way for the increase of plant yield [76].

Seed weight is considered an ecologically crucial character in plant progress, by way of influencing the establishment capacity of a seedling, as well as plant height and yield. This was proved by 
Wuff [81], who found that the Desmodium paniculatum seeds of higher biomass produced a high yield. In addition, the EF-LSE treated seeds displayed increased wet and dry weights equated with control, besides improving with an EF-LSE concentration. This was in agreement with the results published by Karthikeyan and Shanmugam [82], who studied the effect of Kappaphycus alvarezii extract on peanuts. Vijayakumar et al. [83] also reported the increase in seed weight of Capsicum annum by treatment with Codium decorticatum EF-LSE. Increased seed weights produced plants with higher height, shoot mass, and yield [84]. Seed weight increase might be due to the production and accumulation of storage oils and several proteins that might promote plant growth abilities [85]. Seeds take in surrounding water, protoplasmic macromolecules by imbibition. The EF-LSEs are actively imbibed in the seed through capillary action, thus increasing biomass. Seeds with higher biomass have been reported to have better seedling growth. Sun et al. [86]. reported that maize seeds with increased biomass had high yields.

The biomass of EF-LSE treated seeds increased with time, thus revealing that the higher imbibing rate occurs at later hours of priming. This is attributed to the active process of enzymatic breakdown and mitosis essential for emergence. The increased imbibing rate of seeds exposed to EF-LSEs is primarily due to the abundance of plant essential nutrients and phytohormone composition of the EF-LSEs. U. lactuca and P. gymnospora primed tomato seeds exhibited higher imbibition rates during later stages of priming and hence were reported as more successful and better candidates for developing effective biostimulants to improve the growth of tomato plants (Hernández-Herrera [9]).

With respect to the biostimulant potentials of seaweed extract, the yield and quality parameters analyzed presented favorable results. The EF-LSE primed seeds observed an increase in yield, attributed to the presence of phyto-hormones and various plant growth promoting elements, as evident from the EDX analysis of the seaweed. Furthermore, the flavour of the cherry tomato fruit is directly proportional to the amount of TSS [87]. The nutritional value of these tomatoes is based on ascorbic acid content, which was also enhanced by the EF-LSE. Lycopene content, which is the reason for the ripening of fruits at an optimum stage, was also enhanced by EF-LSE treatment. Phenolic compounds, an indication of plant innate defense system, were augmented on treatment with seaweed extracts. These results are in agreement with that of Murtic et al. [88].

Since the cherry tomato gene pool, a wild relative of tomato, provides an opportunity to produce more nutritive and resilient tomato cultivar varieties, an attempt to preserve and conserve this inclusive gene pool in gene banks is critical [89]. Additionally, these wild relative crop types are nutritional repositories, whose cultivation shall be enhanced to meet the increasing global food security targets. The establishment of these species can be further stimulated by seed priming techniques. The application of seaweed extracts as a seed priming agent towards the improvement of agronomic traits of cherry tomato have resulted in positive responses to amplified seed germination capabilities, germination energy, and augmented seedling establishment. In addition, seed priming effects have induced a long-lasting priming effect by altering plant and fruit physiology in a favorable way, by increasing their biochemical constituents and fruit yield. Hence, this study proves the potential of $U$. flexuosa as a potential agricultural biostimulant that is both economic and effective.

Author Contributions: K.M.-P.C. and S.S.-N.; methodology, K.M.-P.C.; software, K.M.-P.C. and S.S.-N.; validation, V.S.-R., A.T., S.K., and R.S.; formal analysis, S.S.-N.; investigation, K.M.-P.C., resources, R.P., and A.T.; data curation, S.S.-N.; writing — original draft preparation, K.M.-P.C.; writing-review and editing, K.M.-P.C., and S.S.-N.; visualization, K.M.-P.C.,V.S.-R., N.S.S., H.S. and R.P.; supervision, S.S.-N.; project administration, R.S.; funding acquisition, S.S.-N.

Funding: This research was funded by the Department of Biotechnology, Ministry of Science and Technology grant number BT/IN/Indo-US/Foldscope//39/2015 dated 20 April 2018.

Conflicts of Interest: The authors declare no conflict of interest. The funders had no role in the design of the study; in the collection, analyses, or interpretation of data; in the writing of the manuscript, or in the decision to publish the results. 


\section{Abbreviations}

$\begin{array}{ll}\text { LSE } & \text { Liquid seaweed extract } \\ \text { EF } & \text { Ulva flexuosa } \\ \text { SFS } & \text { Starter Fertilizer Solution } \\ \text { EDS } & \text { Energy Dispersive Spectroscopy } \\ \text { MGT } & \text { Mean Germination Time } \\ \text { SVI } & \text { Seedling Vigour Index } \\ \text { GE } & \text { Germination Energy } \\ \text { GP } & \text { Germination Percentage }\end{array}$

\section{References}

1. Maarten, E.; Florian, S. Global demand for food is rising. Can we meet it? Available online: https: //hbr.org/2016/04/global-demand-for-food-is-rising-can-we-meet-it (accessed on 9 September 2019).

2. Food and Agriculture Organization; International Fund for Agricultural Development; UNICEF; World Food Programme; WHO. The state of food security and nutrition in the world 2017: Building resilience for peace and food security. 2017. Available online: http://www.fao.org/3/a-i7695e.pdf (accessed on 6 April 2019).

3. Senthil-Nathan, S. A review of biopesticides and their mode of action against insect pests. In Environmental Sustainability; Springer India: New Delhi, India, 2015; pp. 49-63.

4. Hajjar, R.; Hodgkin, T. The use of wild relatives in crop improvement: A survey of developments over the last 20 years. Euphytica 2007, 156, 1-13. [CrossRef]

5. Senthil-Nathan, S. Natural pesticide research. Physiol. Mol. Plant Pathol. 2018, 101, 1-2. [CrossRef]

6. Chanthini, K.; Kumar, C.S.; Kingsley, S.J. Antifungal activity of seaweed extracts against phytopathogen Alternaria solani. J. Acad. Indus. Res. 2012, 1, 86-90.

7. Khan, W.; Rayirath, U.P.; Subramanian, S.; Jithesh, M.N.; Rayorath, P.; Hodges, D.M.; Critchley, A.T.; Craigie, J.S.; Norrie, J.; Prithiviraj, B. Seaweed Extracts as Biostimulants of Plant Growth and Development. J. Plant Growth Regul. 2009, 28, 386-399. [CrossRef]

8. Anisimov, M.M.; Chaikina, E.L.; Klykov, A.G.; Rasskazov, V.A. Effect of seaweeds extracts on the growth of seedling roots of buckwheat (Fagopyrum esculentum Moench) is depended on the season of algae collection. Agric. Sci. Dev. 2013, 2, 67-75.

9. HernÃ jndez-Herrera, R.M.; Santacruz-Ruvalcaba, F.; Ruiz-LÃ3pez, M.A.; Norrie, J.; HernÃ jndez-Carmona, G. Effect of liquid seaweed extracts on growth of tomato seedlings (Solanum lycopersicum L.). J. Applied Phycol. 2014, 26, 619-628. [CrossRef]

10. Hernández-Herrera, R.M.; Santacruz-Ruvalcaba, F.; Briceño-Domínguez, D.R.; Di Filippo-Herrera, D.A. Seaweed as potential plant growth stimulants for agriculture in Mexico. Hidrobiológica 2018, 28, 129-140. [CrossRef]

11. Rengasamy, K.R.; Kulkarni, M.G.; Papenfus, H.B.; Van Staden, J. Quantification of plant growth biostimulants, phloroglucinol and eckol, in four commercial seaweed liquid fertilizers and some by-products. Algal. Res. 2016, 20, 57-60. [CrossRef]

12. Lanka, S.K.; Senthil-Nathan, S.; Blouin, D.J.; Stout, M.J. Impact of thiamethoxam seed treatment on growth and yield of rice, Oryza sativa. J. Econ. Entomol. 2017, 110, 479-486. [CrossRef]

13. Baskin, C.C.; Baskin, J.M. Ecologically Meaningful Germination Studies, Seeds: Ecology, Biogeography, and, Evolution of Dormancy and Germination; Elseiver: New York, NY, USA, 1998.

14. Martinez, E.; Carbonell, M.V.; FlÃrez, M.; Amaya, J.M.; Maqueda, R. Germination of tomato seeds (Lycopersicon esculentum L.) under magnetic field. Int. Agrophys. 2009, 23, 45-49.

15. Soltani, E.; Ghaderi-Far, F.; Baskin, C.C.; Baskin, J.M. Problems with using mean germination time to calculate rate of seed germination. Aust. J. Bot. 2016, 63, 631-635. [CrossRef]

16. Charlo, H.; Castoldi, R.; Ito, L.; Fernandes, C.; Braz, L. Productivity of cherry tomatoes under protected cultivation carried out with different types of pruning and spacing. In Proceedings of the XXVII International Horticultural Congress-IHC2006: International Symposium on Advances in Environmental Control, Automation, Seoul, Korea, 13-19 August 2006; Volume 761, pp. 323-326. 
17. Lin, T.; Zhu, G.; Zhang, J.; Xu, X.; Yu, Q.; Zheng, Z.; Zhang, Z.; Lun, Y.; Li, S.; Wang, X.; et al. Genomic analyses provide insights into the history of tomato breeding. Nat. Genet. 2014, 46, 120. [CrossRef] [PubMed]

18. Wang, P.; Zhong, R.-B.; Yuan, M.; Gong, P.; Zhao, X.-M.; Zhang, F. Mercury (II) detection by water-soluble photoluminescent ultra-small carbon dots synthesized from cherry tomatoes. Sci. Tech. 2016, $27,35$. [CrossRef]

19. Sadasivam, S. Biochemical Methods, 2nd ed.; New Age International (p) Ltd. Publisher: New Delhi, India, 1996; p. 179.

20. Senthil-Nathan, S. Physiological and biochemical effect of neem and other Meliaceae plants secondary metabolites against Lepidopteran insects. Front. Physiol. 2013, 4, 359. [CrossRef] [PubMed]

21. Sadasivam, S.; Manickam, A. Chlorophylls. In Biochemical Methods for Agricultural Sciences; Wiley Eastern Limited: New Delhi, India, 1992; pp. 184-185.

22. Lowry, O.H.; Rosebrough, N.J.; Farr, A.L.; Randall, R.J. Protein measurement with the Folin phenol reagent. J. Boil. Chem. 1951, 193, 265-275.

23. Ellis, R.H.; Roberts, E.H. Improved Equations for the Prediction of Seed Longevity. Ann. Bot. 1980, 45, 13-30. [CrossRef]

24. Orchard, T.J. Estimating the parameters of plant seedling emergence. Seed Sci. Technol. 1977, 5, 61-69.

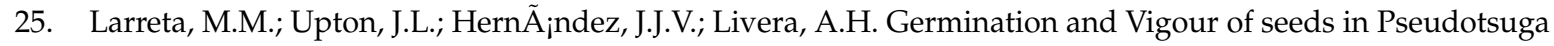
Menziesii of Mexico. Ra. Ximhai 2008, 4, 119-134. [CrossRef]

26. Crop production techniques of horticultural crops. Available online: http://agritech.tnau.ac.in/pdf/2013/cpg horti_2013.pdf (accessed on 4 December 2019).

27. Hedge, J.E.; Hofreiter, B.T.; Whistler, R.L. Carbohydrate Chemistry; Academic Press: New York, NY, USA, 1962; Volume 17.

28. Horwitz, W.; Chichilo, P.; Reynolds, H. Official Methods of Analysis of the Association of Official Analytical Chemists; Association of Official Analytical Chemists: Washington, DC, USA, 1970.

29. Rangana, S. Manual of Analysis of Fruit and Vegetable Products; Tata McGraw-Hill: New Delhi, India, 1979.

30. Priyadharshini, S.; Arya, S.; Kiran, G.S.; Ninawe, A.S.; Selvin, J. Bioactive Marine Natural Products: Insights into Marine Microbes, Seaweeds, and Marine Sponges as Potential Sources of Drug Discovery. In Marine Microorganisms; CRC press: Boca Raton, FL, USA, 2016; pp. 17-30.

31. Godfray, H.C.J.; Garnett, T.; Godfray, H.C.J. Food security and sustainable intensification. Philos. Trans. Soc. B Boil. Sci. 2014, 369, 20120273. [CrossRef] [PubMed]

32. Seethalakshmi, S.; Umarani, R. Biochemical changes during imbibition stages of seed priming in Tomato. Int. J. Cosmet. Sci. 2018, 6, 454-456.

33. Craigie, J.S. Seaweed extract stimuli in plant science and agriculture. J. Appl. Phycol. 2011, 23, 371-393. [CrossRef]

34. Kalaivani, K.; Kalaiselvi, M.M.; Senthil-Nathan, S. Effect of methyl salicylate (MeSA), an elicitor on growth, physiology and pathology of resistant and susceptible rice varieties. Sci. Rep. 2016, 6, 34498. [CrossRef] [PubMed]

35. A Basic Guide to $\mathrm{pH}$ and EC and How They Affect Plants. available online: http://www.plant-magic.co.uk/ post/2016/12/16/a-basic-guide-to-ph-and-ec-and-how-they-affect-plants/54/ (accessed on 4 October 2018).

36. Elia, A.; Serio, F.; Parente, A.; Santamaria, P.; Ruiz Rodriguez, G. Electrical conductivity of nutrient solution, plant growth and fruit quality of soilless grown tomato. In Proceedings of the V International Symposium on Protected Cultivation in Mild Winter Climates: Current Trends for Suistainable Technologies, Cartagena, Spain, 7 March 2000; Volume 559, pp. 503-508.

37. Krauss, S.; Schnitzler, W.H.; Grassmann, J.; Woitke, M. The Influence of Different Electrical Conductivity Values in a Simplified Recirculating Soilless System on Inner and Outer Fruit Quality Characteristics of Tomato. J. Agric. Food. Chem. 2006, 54, 441-448. [CrossRef]

38. Ding, X.; Jiang, Y.; Zhao, H.; Guo, D.; He, L.; Liu, F.; Zhou, Q.; Nandwani, D.; Hui, D.; Yu, J. Electrical conductivity of nutrient solution influenced photosynthesis, quality, and antioxidant enzyme activity of pakchoi (Brassica campestris L. ssp. chinensis) in a hydroponic system. PLoS ONE 2018, 13, 0202090. [CrossRef] [PubMed]

39. Samarakoon, U.C.; Weerasinghe, P.A.; Weerakkody, W.A.P. Effect of electrical conductivity (EC) of the nutrient solution on nutrient uptake, growth and yield of leaf lettuce (Lactuca sativa L.) in stationary culture. Trop. Agric. Res. 2006, 18. 
40. Hernández-Herrera, R.M.; Santacruz-Ruvalcaba, F.; Zañudo-Hernandez, J.; Hernández-Carmona, G. Activity of seaweed extracts and polysaccharide-enriched extracts from Ulva lactuca and Padina gymnospora as growth promoters of tomato and mung bean plants. J. Appl. Phycol. 2016, 28, 2549-2560. [CrossRef]

41. Koh, Y. The Effect of Oligosaccharides in an Extract of the Brown Seaweed Ascophyllum nodosum on Plant Growth and Plant Immune Responses in Soybean (Glycine max L.) and Duckweed (Lemna minor). Ph.D. Thesis, The Saint Mary's University, Halifax, NS, Canada, April 2016.

42. Mzibra, A.; Aasfar, A.; El Arroussi, H.; Khouloud, M.; Dhiba, D.; Kadmiri, I.M.; Bamouh, A. Polysaccharides extracted from Moroccan seaweed: A promising source of tomato plant growth promoters. J. Appl. Phycol. 2018, 30, 2953-2962. [CrossRef]

43. Paul, J. Influence of seaweed liquid fertilizer of Gracilaria dura (AG.) J. A. G. (red seaweed) on Vigna radiata (1.) r. wilczek., in Thoothukudi, Tamil Nadu, India. World J. Pharm Res. 2014, 3, 968-978.

44. Polo, J.; Mata, P. Evaluation of a Biostimulant (Pepton) Based in Enzymatic Hydrolyzed Animal Protein in Comparison to Seaweed Extracts on Root Development, Vegetative Growth, Flowering, and Yield of Gold Cherry Tomatoes Grown under Low Stress Ambient Field Conditions. Front. Plant Sci. 2018, 8, 2261. [CrossRef] [PubMed]

45. Van Oosten, M.J.; Pepe, O.; De Pascale, S.; Silletti, S.; Maggio, A. The role of biostimulants and bioeffectors as alleviators of abiotic stress in crop plants. Chem. Boil. Technol. Agric. 2017, 4, 3. [CrossRef]

46. Corona, G.; Coman, M.M.; Guo, Y.; Hotchkiss, S.; Gill, C.; Yaqoob, P.; Spencer, J.P.E.; Rowland, I.; Spencer, J.P.J.P.E. Effect of simulated gastrointestinal digestion and fermentation on polyphenolic content and bioactivity of brown seaweed phlorotannin-rich extracts. Mol. Nutr. Food Res. 2017, 61, 1700223. [CrossRef] [PubMed]

47. Austin, C.; Stewart, D.; Allwood, J.W.; McDougall, G.J. Extracts from the edible seaweed, Ascophyllum nodosum, inhibit lipase activity in vitro: Contributions of phenolic and polysaccharide components. Food Funct. 2018, 9, 502-510. [CrossRef] [PubMed]

48. Rajauria, G.; Foley, B.; Abu-Ghannam, N. Identification and characterization of phenolic antioxidant compounds from brown Irish seaweed Himanthalia elongata using LC-DAD-ESI-MS/MS. Innov. Food Sci. Emerg. Technol. 2016, 37, 261-268. [CrossRef]

49. Farasat, M.; Khavari-Nejad, R.-A.; Nabavi, S.M.B.; Namjooyan, F. Antioxidant Activity, Total Phenolics and Flavonoid Contents of some Edible Green Seaweeds from Northern Coasts of the Persian Gulf. Iran. J. Pharm. IJPR 2014, 13, 163-170.

50. Lola-Luz, T.; Hennequart, F.; Gaffney, M. Effect on yield, total phenolic, total flavonoid and total isothiocyanate content of two broccoli cultivars (Brassica oleraceae var italica) following the application of a commercial brown seaweed extract (Ascophyllum nodosum). Agric. Food Sci. 2014, 23, 28-37. [CrossRef]

51. Faizal, A.; Geelen, D. Saponins and their role in biological processes in plants. Phytochem. Rev. 2013, 12, 877-893. [CrossRef]

52. Saleh, A.M.; Madany, M.M.Y.; GonzÃ $j$ lez, L. The effect of coumarin application on early growth and some physiological parameters in Faba Bean (Vicia faba L.). Plant Growth Regul. 2015, 34, 233-241. [CrossRef]

53. Chattha, F.A.; Munawar, M.A.; Ashraf, M.; Kousar, S.; Nisa, M.U. Plant growth regulating activities of coumarin-3-acetic acid derivatives. Allelopathy J. 2015, 36.

54. Tuhy, Ł.; Samoraj, M.; Basladynska, S.; Chojnacka, K. New Micronutrient Fertilizer Biocomponents Based on Seaweed Biomass. Pol. J. Environ. Stud. 2015, 24, 2213-2221. [CrossRef]

55. Palta, J.P. Leaf chlorophyll content. Remote Sens. Rev. 1990, 5, 207-213. [CrossRef]

56. Rathod, P.J. Metabolomics and morphological characterization of macroalgae. Ph.D. Thesis, Junagadh Agricultural University, Junagadh, India, 2018.

57. Farvin, K.S.; Jacobsen, C. Phenolic compounds and antioxidant activities of selected species of seaweeds from Danish coast. Food Chem. 2013, 138, 1670-1681. [CrossRef] [PubMed]

58. Ciepiela, G.Y.A.; Godlewska, A.; Jankowska, J. The effect of seaweed Ecklonia maxima extract and mineral nitrogen on fodder grass chemical composition. Environ. Sci. Pollut. R. 2016, 23, 2301-2307. [CrossRef] [PubMed]

59. Butola, J.S.; Badola, H.K. Effect of pre-sowing treatment on seed germination and seedling vigour in Angelica glauca, a threatened medicinal herb. Curr. Sci. 2004, 87, 796-799.

60. Tzortzakis, G.N. Effect of pre-sowing treatment on seed germination and seedling vigour in endive and chicory. Hort. Sci. 2009, 36, 117-125. [CrossRef] 
61. Yildirim, E.; Dursun, A.; GÃvenc, I.; Kumlay, A.M. The effects of different salt, biostimulant and temperature levels on seed germination of some vegetable species. In Proceedings of the II Balkan Symposium on Vegetables and Potatoes, Thessaloniki, Greece, 11 October 2000; Volume 579, pp. 249-253.

62. Hassan, S.M.; Ghareib, H.R. Bioactivity of Ulva lactuca L. acetone extract on germination and growth of lettuce and tomato plants. Afr. J. Biotechnol. 2009, 8.

63. Patel, R.V.; Pandya, K.Y.; Jasrai, R.T.; Brahmbhatt, N. Significance of Green and Brown Seaweed Liquid Fertilizer on Seed Germination of Solanum melongena, Solanum lycopersicum and Capsicum annum by Paper Towel and Pot Method. Int. J. Recent Sci. Res. 2018, 9, 24065-24072.

64. Demir, N.; Dural, B.; Yildirim, K. Effect of seaweed suspensions on seed germination of tomato, pepper and aubergine. J. Biol. Sci. 2006, 6, 1130-1133.

65. Senn, T.L.; Aitken, J.B. Seaweed Products as a Fertilizer and Soil Conditioner for Horticultural Crops. Bot. Mar. 1965, 8, 144-147.

66. Dhargalkar, V.K.; Untawale, A.G. Some observations of the effect of SLF on higher plants. Indian J. Mar. Sci. 1983, 12, 210-214.

67. Kavipriya, R.; Dhanalakshmi, P.K.; Jayashree, S.; Thangaraju, N. Seaweed extract as a biostimulant for legume crop, green gram. J. Ecobiotechnol. 2011, 3, 16-19.

68. Amabika, S.; Sujatha, K. Effect of priming with seaweed extracts on germination and vigour under different water holding capacities. Seaweed Res. Utiln 2015, 37, 37-44.

69. Kumar, N.A.; Vanlalzarzova, B.; Sridhar, S.; Baluswami, M. Effect of liquid seaweed fertilizer of Sargassum wightii Grev. on the growth and biochemical content of green gram (Vigna radiata (L.) R. Wilczek). Recent Res. Sci. Technol. 2012, 4, 40-45.

70. Ganapathy Selvam, G.; Balamurugan, M.; Thinakaran, T.; Sivakumar, K. Developmental changes in the germination, growth and chlorophyllase activity of Vigna mungo L. using seaweed extract of Ulva reticulata Forsskal. Int. Res. J. Pharm. 2013, 4, 252-254.

71. Khatami, S.R.; Sedghi, M.; Garibani, H.M.; Ghahremani, S. The effect of priming on seed germination characteristics of maize under salt stress. In Annales of West University of Timisoara. Series of Biology; West University of Timisoara: Timișoara, Romania, 2017; Volume 20, p. 65.

72. Basra, S.; Farooq, M.; Tabassam, R.; Ahmad, N. Physiological and biochemical aspects of pre-sowing seed treatments in fine rice (Oryza sativa L.). Seed Sci. Technol. 2005, 33, 623-628. [CrossRef]

73. Kumar, G.; Sahoo, D. Effect of seaweed liquid extract on growth and yield of Triticum aestivum var. Pusa Gold. J. Appl. Phycol. 2011, 23, 251-255. [CrossRef]

74. Castellanos-Barriga, L.G.; Santacruz-Ruvalcaba, F.; Hernández-Carmona, G.; Ramírez-Briones, E.; Hernández-Herrera, R.M. Effect of seaweed liquid extracts from Ulva lactuca on seedling growth of mung bean (Vigna radiata). J. Appl. Phycol. 2017, 29, 2479-2488. [CrossRef]

75. Zodape, S.T.; Gupta, A.; Bhandari, S.C.; Rawat, U.S.; Chaudhary, D.R.; Eswaran, K.; Chikara, J. Foliar application of seaweed sap as biostimulant for enhancement of yield and quality of tomato (Lycopersicon esculentum Mill.). J. Sci. Ind. Res. 2011, 70, 215-219.

76. Di Filippo-Herrera, D.A.; Muñoz-Ochoa, M.; Hernández-Herrera, R.M.; Hernández-Carmona, G. Biostimulant activity of individual and blended seaweed extracts on the germination and growth of the mung bean. J. Appl. Phycol. 2018, 33, 1-13. [CrossRef]

77. Arioli, T.; Mattner, S.W.; Winberg, P.C. Applications of seaweed extracts in Australian agriculture: Past, present and future. J. Appl. Phycol. 2015, 27, 2007-2015. [CrossRef] [PubMed]

78. Battacharyya, D.; Babgohari, M.Z.; Rathor, P.; Prithiviraj, B. Seaweed extracts as biostimulants in horticulture. Sci. Hortic. 2015, 196, 39-48. [CrossRef]

79. Rayorath, P.; Jithesh, M.N.; Farid, A.; Khan, W.; Palanisamy, R.; Hankins, S.D.; Critchley, A.T.; Prithiviraj, B. Rapid bioassays to evaluate the plant growth promoting activity of Ascophyllum nodosum (L.) Le Jol. using a model plant, Arabidopsis thaliana (L.) Heynh. J. Appl. Phycol. 2008, 20, 423-429. [CrossRef]

80. Ghaderiardakani, F.; Collas, E.; Damiano, D.K.; Tagg, K.; Graham, N.S.; Coates, J. Effects of green seaweed extract on Arabidopsis early development suggest roles for hormone signalling in plant responses to algal fertilisers. Sci. Rep. 2019, 9, 1983. [CrossRef] [PubMed]

81. Wulff, R.D. Seed size variation in Desmodium paniculatum: III. Effects on reproductive yield and competitive ability. J. Ecol. 1986, 74, 115-121. [CrossRef] 
82. Karthikeyan, K.; Shanmugam, M. Grain yield and functional properties of red gram applied with seaweed extract powder manufactured from Kappaphycus alvarezii. Int. J. Rec. Adv. Mul. Dis. Res. 2016, 3, 1353-1359.

83. Vijayakumar, S.; Durgadevi, S.; Arulmozhi, P.; Rajalakshmi, S.; Gopalakrishnan, T.; Parameswari, N. Effect of seaweed liquid fertilizer on yield and quality of Capsicum annum L. Acta Ecol. Sin. 2018, in press. [CrossRef]

84. Poveda, K.; Steffan-Dewenter, I.; Scheu, S.; Tscharntke, T. Effects of below- and above-ground herbivores on plant growth, flower visitation and seed set. Oecologia 2003, 135, 601-605. [CrossRef]

85. Baud, S.; Boutin, J.-P.; Miquel, M.; Lepiniec, L.; Rochat, C. An integrated overview of seed development in Arabidopsis thaliana ecotype WS. Plant Physiol. Biochem. 2002, 40, 151-160. [CrossRef]

86. Sun, X.; Cahill, J.; Van Hautegem, T.; Feys, K.; Whipple, C.; Novák, O.; Delbare, S.; Versteele, C.; Demuynck, K.; De Block, J.; et al. Altered expression of maize PLASTOCHRON1 enhances biomass and seed yield by extending cell division duration. Nat. Commun. 2017, 8, 14752. [CrossRef] [PubMed]

87. Venkadeswaran, E.; Vethamoni, P.I.; Arumugam, T.; Manivannan, N.; Harish, S. Evaluating the yield and quality characters of cherry tomato [Solanum lycopersicum (L.) var. cerasiforme Mill.] genotypes. Int. J. Chem. Stud. 2018, 6, 858-863.

88. Murtic, S.; Oljaca, R.; Murtic, M.S.; Vranac, A.; Koleska, I.; Karic, L. Effects of seaweed extract on the growth, yield and quality of cherry tomato under different growth conditions. Acta Agric. Slov. 2018, 111, 315-325. [CrossRef]

89. Castañeda-Álvarez, N.P.; Khoury, C.K.; Achicanoy, H.A.; Bernau, V.; Dempewolf, H.; Eastwood, R.J.; Guarino, L.; Harker, R.H.; Jarvis, A.; Maxted, N.; et al. Global conservation priorities for crop wild relatives. Nat. Plants 2016, 2, 16022. [CrossRef] [PubMed]

(C) 2019 by the authors. Licensee MDPI, Basel, Switzerland. This article is an open access article distributed under the terms and conditions of the Creative Commons Attribution (CC BY) license (http://creativecommons.org/licenses/by/4.0/). 